\title{
Simulasi Tampungan Bendung Gerak Sembayat Sebagai Longstorage Untuk Pemenuhan Kebutuhan Air Baku Dan Irigasi Di Kabupaten Lamongan Dan Wilayah Utara Kabupaten Gresik
}

\author{
Mona Is Aziza ${ }^{1, *}$, Wasis Wardoyo ${ }^{1}$, Nadjadji Anwar ${ }^{1}$ \\ Departemen Teknik Sipil, ITS, Surabaya ${ }^{1}$ \\ Koresponden*, Email: monaisaziza@gmail.com
}

\begin{tabular}{l}
\hline \multicolumn{1}{c}{ Info Artikel } \\
\hline Diajukan 28 Juli 2017 \\
Diperbaiki 6 Desember 2017 \\
Disetujui 7 Desember 2017
\end{tabular}

Keywords: Sembayat Barrage, Long Storage, Data Generated Thomas Fiering, Water Balance

Kata kunci: Bendung Gerak Sembayat, Long Storage, Pembangkitan Data Thomas Fiering, Water Balance

\begin{abstract}
Sembayat Barrage is located in the village of Sragen, District Bungah, Gresik around $29 \mathrm{~km}$ from Bengawan Solo river mouth upstream downstream. Extensive reservoirs of BGS is from Babat to Sembayat Barrage is $\pm 1487 \mathrm{~km}^{2}$. Bengawan Solo river basin hydrological circumstances Downstream in critical condition, as a result, most of the Bengawan Solo river basin downstream located in the district of North Gresik and Lamongan, annually flooded by the overflow of water from upstream. Instead upstream of Lamongan is always a shortage of water in the dry season. This study will utilize Sembayat Barrage as long storage reservoirs that can store water during the dry season and can drain the water in the rainy season. Inflow reservoirs BGS obtained by the data generation method using Thomas Fiering. Data on average daily debit every month for 24 years raised to statistical flow data that can be used during the next 50 years. Calculation of raw water requirements based on criteria of clean water planning Directorate General of Human Settlements, Ministry of Public Works in 2000, while the irrigation water needs are calculated based on the Standard Planning Irrigation (KP-01) in 1986. There are 6 simulation to get the most optimal results. Eleven of these alternatives is processed by the method of Water Balance to analyze the needs of water for fishing, irrigation, domestic and industrial. The results of the simulation of alternative obtained the most optimal based quadrant graph that is on the water balance of Existing grains-Crops Crops with a total water demand $61411.61\left(10^{6} \mathrm{~m}^{3}\right)$.
\end{abstract}

\begin{abstract}
Abstrak
Bendung Gerak Sembayat (BGS) terletak di Desa Sragen, Kecamatan Bungah, Gresik sekitar $29 \mathrm{~km}$ dari arah hilir sungai Bengawan Solo hulu hilir. Luas waduk BGS adalah dari Babat sampai ke Sembayat Barrage \pm 1487 km$^{2}$. DAS Bengawan Solo keadaan hidrologi Hilir dalam kondisi kritis, akibatnya, sebagian besar DAS Bengawan Solo hilir terletak di Kabupaten Gresik Utara dan Lamongan, setiap tahunnya dibanjiri oleh luapan air dari hulu. Sebaliknya hulu Lamongan selalu kekurangan air di musim kemarau. Studi ini akan memanfaatkan Bendung Gerak Sembayat sebagai reservoir penampung yang bisa menyimpan air selama musim kemarau dan bisa menguras air di musim hujan. Inflow waduk BGS diperoleh dengan metode pembangkitan data menggunakan Thomas Fiering. Data rata-rata debit harian setiap bulan selama 24 tahun dinaikkan menjadi data arus statistik yang bisa digunakan selama 50 tahun ke depan. Perhitungan kebutuhan air baku berdasarkan kriteria perencanaan air bersih Direktorat Jenderal Cipta Karya, Kementerian Pekerjaan Umum tahun 2000, sedangkan kebutuhan air irigasi dihitung berdasarkan Standar Perencanaan Irigasi (KP-01) pada tahun 1986. Ada 6 simulasi Untuk mendapatkan hasil yang paling optimal. Sebelas alternatif ini diproses dengan metode Water Balance untuk menganalisis kebutuhan air untuk perikanan, irigasi, domestik dan industri. Hasil simulasi alternatif diperoleh grafik kuadran optimal paling optimal yaitu pada neraca air Tanaman Biji-bijian yang ada dengan total kebutuhan air $61411.61\left(10^{6} \mathrm{~m}^{3}\right)$
\end{abstract}

\section{Pendahuluan}

Kegiatan pengembangan sumber daya air yang meliputi perencanaan umum, teknis, pelaksanaan fisik, operasi dan pemeliharaan serta kegiatan dalam penelitian, penilaian, dan pembangunan berjalan kurang seimbang dengan perubahan keadaan yang sangat cepat baik di tingkat lokal, nasional, regional, dan Global [1] Pada musim kemarau panen di wilayah Solo Hilir dari babat sampai Sembayat mengalami kekurangan air sehingga menghasilkan hasil yang rendah. Perkembangan irigasi dan pertanian di wilayah ini masih rendah dibandingkan dengan daerah aliran sungai madiun, sedangkan potensi lahan pertanian masih banyak dan banyak yang tidak dapat dimanfaatkan karena kekurangan air. Selain itu, eksploitasi air irigasi merupakan kunci pertumbuhan ekonomi bagi kawasan hilir Solo. Kurangnya air di musim kemarau memiliki beberapa penyebab, antara lain, kondisi 
geografis, kondisi penggunaan lahan, kondisi geologi saling terkait dengan iklim, curah hujan, kemampuan tanah, dan kualitas dan kuantitas air [2].

Bendung Gerak Sembayat telah direncanakan untuk mengatasi masalah kekurangan air dan kelebhan air di daerah aliran sungai ini. Daerah aliran sungai merupakan daerah utara Kabupaten Gresik dan beberapa kabupaten Lamongan. Rencana untuk bendung gerak ini menggunakan beberapa alternatif yang memungkinkan debit yang dapat diandalkan dalam 5 sampai 10 tahun ke depan. Pasang weir bendung gerak sembayat adalah babat. Letak Bendung Gerak Sembayat ada di desa Sragen, Kecamatan Bungah, Gresik sekitar 29 km dari arah hilir sungai Bengawan Solo hulu hilir. Menurut Pola Pengembangan DAS Sumber Daya Air (NRMWS) Wilayah Sungai Tengah (BBWS) Bengawan Solo, Bendung Gerak Sembayat direncanakan untuk memasok air baku ke Rencana Pengolahan Air seluas $2 \mathrm{~m}^{3} / \mathrm{dtk}$, untuk irigasi daerah Gresik seluas 883 ha. Standar air untuk Industri dan Rumah Tangga 1,45 $\mathrm{m}^{3} / \mathrm{dtk}$ dan tambak 3,9 $\mathrm{m}^{3} / \mathrm{dtk}$. Ini bertujuan untuk mengatur pengelolaan sumber daya air secara efektif dan optimal untuk memperbaiki pelestarian pemanfaatan sumber daya alam secara lestari dan mengurangi risiko kerusakan air dan mampu mengatasi kesulitan air baku terutama di musim kemarau.

Bendung Gerak Sembayat ini diharapkan bisa berfungsi optimal untuk memenuhi kebutuhan air domestik, industri, irigasi, dan perikanan untuk wilayah Lamongan dan Gresik. Oleh karena itu diperlukan suatu penelitian untuk mendapatkan cara optimal untuk memenuhi kebutuhan air pada Bendung Gerak Sembayat salah satunya adalah memanfaatkan tampungan sungai sepanjang bendungan sehingga ketersediaan air pada Bendung Gerak Sembayat tidak hanya mengandalkan arus dan debit saja namun dapat memanfaatkan tampungan bendung itu sendiri.

\section{Metodologi}

Penelitian adalah serangkaian langkah yang dilakukan secara terencana dan sistematis untuk mendapatkan pemecahan masalah atau mendapatkan jawaban atas pertanyaan tertentu. Langkah-langkah untuk melakukannya harus harmonis dan saling mendukung satu sama lain, sehingga penelitian yang dilakukan memiliki bobot yang cukup dan memberikan kesimpulan yang tidak ambigu. Langkahlangkah penelitian pada umumnya adalah sebagai berikut.

1. Pengumpulan data sekunder untuk dijadikan bahan penelitian.

2. Lakukan perhitungan debit limpasan dari Bendung Gerak Sembayat.

3. Lakukan perhitungan irigasi air sungai Bengawan Solo
Hilir.

4. Cari tahu air baku untuk domestik, industri, irigasi dan perikanan.

5. Menganalisis neraca air / neraca air Sungai Bengawan Solo Hilir berdasarkan arus masuk dan arus keluar Sungai Bengawan Hilir Solo.

6. Simulasi tampungan untuk mendapatkan tampungan yang optimal.

Setelah mendapatkan data di atas, akan diproses dan dianalisis untuk mendapatkan kesimpulan tentang optimalisasi dari Bendung Gerak Sembayat ini.

\section{Analisis Kebutuhan Air}

Menurut fungsinya sebagai pemasok air baku untuk pengairan, baik dalam negeri maupun industri serta memasok kekurangan air akibat kekeringan, kebutuhan air perlu diprediksi sejak awal untuk memenuhi kebutuhan air bersih. 1. Kebutuhan Air Irigasi. Pola penanaman akan memberikan gambaran umum jenis dan luas panen yang akan dikomersialkan dalam setahun. Dalam penelitian ini, sampel yang akan diambil pada irigasi irigasi yang ada adalah tanaman padi. 2. Kebutuhan Air domestik atau Rumah Tangga. Kebutuhan air untuk keperluan rumah tangga atau rumah tangga dengan nilai rata-rata. 3. Kebutuhan air Perikanan. Kebutuhan air di sektor tambak di daerah sekitar bagian utara Lamongan dan Gresik. 4. Kebutuhan air Industri. Kebutuhan air standar industri ini bdaerah yang akan dikembangkan dan direncanakan jumlah pekerja industri

\section{Analisis Data yang dihasilkan}

Menjelaskan langkah-langkah perhitungan model Thomas-Fiering[3] saat diberi $\mathrm{N}$ tahun:

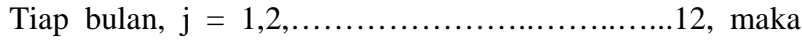
dihitung:

a. Curah Hujan Rata-Rata

$$
X=\frac{1}{n} \sum_{i=1}^{n} X_{i}, b
$$

b. Standard deviasi $(\mathrm{Sj})$

$$
S_{j}=\frac{\overline{\sum_{i} R j i-\bar{R} j^{2}}}{(N-1)}
$$

c. Koefisien korelasi dengan curah hujan bulan sebelumnya (rj)

$$
r j=\frac{R j i-\bar{R} j R_{j+1, i}-\bar{R}_{j+1}{ }^{2}}{\sum i R_{j i}-\bar{R}_{j}{ }^{2} \times \Sigma i R_{j+1, i}-\bar{R}_{j+1}{ }^{2}}
$$

d. Kemiringan persamaan regresi (bj)

$$
b_{j}=\frac{r_{j} S_{j}}{S_{j}}
$$

Hitung deviasi acak normal setiap tahunnya. Kemudian mengembangkan persamaan Thomas-Fiering:

$q_{1, b}=\bar{x}_{b}+\frac{r_{b \cdot S d_{b}}}{S d_{b-1}}\left(q_{i, b-1}-\bar{X}_{b-1}+t_{i, b} \cdot S d_{b} . \overline{\left(1-r_{b}^{2}\right.}\right)$ 


\section{Water Balance}

Dalam mempelajari masalah pola ketersediaan air terlihat sebelumnya karakteristik hidrologi daerah penelitian, dan pola pendistribusian masing-masing daerah yang telah dilakukan pada saat ini. Dengan mengetahui pola distribusi air yang ada maka akan direncanakan kebutuhan dan ketersediaan debit air pada area studi [4].

Metode neraca air (Water Balance) digunakan untuk membandingkan antara tersedianya aliran air yang ada antara ketersediaan debit air yang ada menurut kebutuhan industri dan kebutuhan air dalam negeri setiap bulannya. Analisis awal penelitian ini adalah untuk membandingkan ketersediaan dan kebutuhan air dari kebutuhan air yang ada dengan rencana pola permintaan air. Sebagai ukuran rencana awal pasokan air ke industri dan rumahan yang ada. Kemudian untuk kebutuhan air masing-masing yang diuji kebutuhan air dalam negeri $100 \%$ industri $50 \%$, industri dalam negeri 50\% dan industri dalam negeri 100\% 50\% 50\% dari jumlah industri atau domestik. Sehingga bisa menjadi perencanaan tata ruang kawasan yang akan datang untuk domestik dan industri.

\section{Simulasi Reservoir}

Simulasi Manual dengan data yang ada untuk water balance. Data yang ada adalah data yang digunakan dalam panduan belajar, data akan digunakan untuk menganalisis apakah data yang ada tersedia, pemenuhan air untuk kebutuhan air dari Bendung Gerak Sembayat telah terpenuhi secara penuh. Penelitian ini terdiri dari optimalisasi kebutuhan air terhadap kebutuhan air perikanan, irigasi, domestik dan industri. Pada data yang ada, air irigasi paling banyak mendapat pemenuhan. Oleh karena itu, optimalisasi dilakukan dengan mengubah pola tanam padi sepanjang tahun menjadi tanaman padi-padi-palawija dan tahunnya dengan masing-masing memiliki tiga musim tanam.

Tidak hanya mengoptimalkan irigasi, namun penelitian ini membuat pola alternatif lain untuk mendapatkan hasil yang optimal. Kebutuhan air untuk perikanan, dalam negeri, dan industri juga dioptimalkan untuk mengkolaborasikan beberapa langkah tanam dan 4 macam alternatif. Pola optimasi skema yang ditemukan pada Gambar 1. Pada data yang ada diketahui kebutuhan air yang paling banyak adalah untuk irigasi. Dengan tidak ada perubahan meningkat, daerah irigasi, simulasi menggunakan perubahan pola tanam padi sepanjang tahun menjadi pola tanam padi-padi-palawija dan pola tanam padi-palawija-palawija, dengan harapan dapat meningkatkan pemenuhan air dan mengoptimalkan air pada Bendung Gerak Sembayat itu sendiri.

\section{Hasil dan Pembahasan}

Dalam menentukan daerah aliran sungai, perlu untuk melihat lokasi bangunan air yang akan dianalisis. Dari lokasi tersebut hulu, kemudian ditentukan batas daerah aliran sungai dengan batas antara hilir sungai dari Bendung Gerak Babat hingga hulu sungai di Bendung Gerak Sembayat. Daerah aliran sungai Long storage yang akan disimulasikan terdapat pada Gambar 2 yaitu panjang sungai bengawan solo dari Bendung Gerak Babat sampai Bendung Gerak Sembayat. Bendung Gerak Sembayat memiliki pintu bendung berukuran lebar 196,75 m dengan tinggi $10 \mathrm{~m}$ dan panjang tampungannya adalah $29 \mathrm{~km}$ (Bendung Gerak Babat). Bendung Gerak Sembayat memiliki kapasitas penyimpanan sekitar 7 juta $\mathrm{m} 3$. Bendungan memiliki pintu bendung berukuran lebar 196,75 m dengan tinggi $10 \mathrm{~m}$ dan panjang tampungannya adalah $29 \mathrm{~km}$ (dari Bendung Gerak Babat). Bendung Gerak Sembayat memiliki kapasitas penyimpanan sekitar 7 juta $\mathrm{m} 3$.

Pada Gambar 3, menggambarkan distribusi air yang digunakan dari Bendung Gerak Sembayat. Secara umum Bendung Gerak Sembayat berfungsi untuk memenuhi kebutuhan air selama musim kemarau dan mencegah banjir pada musim hujan. Dalam penelitian ini, data debit yang digunakan adalah data debit yang sama yang digunakan dalam perencanaan Bendung Gerak Sembayat dengan data akan dihasilkan selama 50 tahun. Kebutuhan penyaluran air di atas adalah harapan bahwa Bendung Gerak Sembayat akan beroperasi saat dioperasikan.

\section{Analisa Kebutuhan Air}

1. Kebutuhan Air untuk Irigasi

Bendung Gerak Sembayat ini rencananya akan mengairi sistem irigasi pada sawah rawa jebung yaitu di lahan seluas 17181 hektare dan sawah yang telah ditanami padi di tepi kiri sungai seluas $3.752 \mathrm{Ha}$. Luas lahan yang ditanami atau irigasi $=17171 \mathrm{Ha}+3752 \mathrm{Ha}=20933$ ha. Berdasarkan SNI 19-6728.1-2002, menghitung kebutuhan air untuk irigasi adalah: $\mathrm{A}=20933 \mathrm{ha} \times 0,001 \mathrm{~m} / \mathrm{det} / \mathrm{ha}=20,933 \mathrm{~m} 3 /$ detik. 2. Kebutuhan Domestik dan Industri

Air yang mengalir dari Bendung Gerak Sembayat juga digunakan untuk memenuhi kebutuhan air dalam negeri (rumah tangga) dan pasokan air untuk industri sekitar 1.000 ha. Rumah tangga $=(1.187 .795$ jiwa penduduk +548421 jiwa) $* 0: 12 \mathrm{~m}^{3} / \mathrm{dtk}=2.4114$ dan Industri $=0,7 \mathrm{~L} / \mathrm{dtk} \times 8000$ ha $=5600 \mathrm{~L} / \mathrm{dtk}=5,6 \mathrm{~m}^{3} / \mathrm{dtk}$.

3. Perlengkapan Air Untuk Perikanan

Bendung Gerak Sembayat juga akan difungsikan untuk mengairi kolam ikan di Kecamatan Bungah seluas 3.250 Ha. Sedangkan kebutuhan air untuk perikanan adalah 0,0059 
m3/dtk/ha. Kebutuhan Air untuk perikanan: 3250 ha x 0,0059 $\mathrm{m}^{3} / \mathrm{dtk} / \mathrm{ha}=19,1750 \mathrm{~m}^{3} / \mathrm{dtk}$. Tabel 1 menunjukkan jenis dan jumlah air yang harus disuplai Bendung Gerak Sembayat.

\section{Metode Analisis Pembangkitan Debit dengan Thomas Fiering}

Masukan ke metode Thomas Fiering dalam uji coba simulasi meramalkan debit rata-rata bulanan $\left(\mathrm{m}^{3} / \mathrm{dtk}\right)$ selama 24 tahun. Debet rata-rata bulanan dari tahun 1981 sampai 2004 akan diperpanjang sampai tahun 2054. Untuk memperpanjang debit sampai sepuluh tahun diperlukan parameter seperti standar deviasi.

Untuk menghasilkan data debit bisa digunakan model Thomas Fiering. Langkah-langkahnya adalah sebagai berikut langkahnya:

1. Mengumpulkan data debit harian setiap hari akan dibangkitkan kembali pada Tabel 2,

2. Hitung debit rata-rata setiap bulan debit data debit BGS (contoh),

3. Q rata-rata Januari $=(645,6+1305,8+807,8+1160+\ldots$ $. .+951,3) / 24=823,2$,

4. Menghitung deviasi standar tiap bulan,

5. Menghitung koefisien korelasi serial data debit arus masuk bulanan,

6. Menghitung koefisien regresi bulanan yang ditunjukkan pada Tabel 3,

7. Menghitung nomor acak seragam antara 0 dan 1 dibuat dengan program komputer Excel 2010 dan diubah menjadi standar normal pembagian bilangan acak dengan nilai median 0 dan variasi 1 ,

8. Hitung bilangan acak normal,

9. Menghitung perpanjangan data debit selama 50 tahun yang ditunjukkan pada Tabel 4.

\section{Simulasi Air dan Simulasi Reservoir}

Keseimbangan air digunakan untuk mengetahui kelebihan atau kekurangan air dalam aliran sungai sehingga bisa dibuat pola operasi Bendung Gerak Sembayat yang sesuai dengan kebutuhan. Berikut ini adalah tabel perhitungan neraca air dalam 1,2, dan 3 sebagai contoh dari Tabel 5. Dari perhitungan neraca air di atas, dapat mengukur tingkat persediaan air pada tahun kering dimana rata-rata debit air masuk ke Bendung Gerak Sembayat lebih kecil dari pada debit yang dibutuhkan.

\section{Simulasi Reservoir}

Dilihat dari kurva dalam memenuhi kebutuhan air Bendung Gerak Sembayat dari tahun 1 sampai dengan tahun 50, disimpulkan bahwa sebagian besar defisit air pada bulan- bulan tertentu. Maka dari itu harus dioptimalkan dalam memenuhi kebutuhan air di air berlebih dan mengoptimalkan defisit air bulan. Penelitian ini akan menggunakan beberapa jenis simulasi pemenuhan air setiap tahun sebagai strategi optimasi, yaitu pada Gambar 4 yang menunjukkan skema strategi optimasi yang memenuhi kebutuhan Bendung Gerak Sembayat.

Optimalisasi ini melibatkan beberapa simulasi yang mengacu pada permintaan air di Bendung Gerak Sembayat yang terdiri dari Perikanan, Irigasi, Domestik dan Industri. Setiap kebutuhan air untuk disimulasikan dengan 4 macam alternatif, yaitu A, B, C, dan D seperti ditunjukkan pada Gambar 4.3.

\section{Simulasi manual dengan data eksisting Pola Tanam Padi Sepanjang Tahun}

Simulasi yang dilakukan dengan data yang ada yang telah dihitung dengan neraca air di atas, melalui pendekatan water balance maka selanjutnya disimulasikan tingkat pemenuhan air setiap bulannya selama 50 tahun dengan metode manual. Data yang ada di lapangan menggunakan pola tanam data eksisting padi sepanjang tahun. Dan kebutuhan lainnya seperti kebutuhan air untuk perikanan, domestik dan industri konstan setiap bulannya. Pada data yang ada telah direncanakan penggunaan air sesuai data yang dicari di lapangan adalah sebagaimana terlihat pada Tabel 6 yang menunjukkan permintaan air pada data padi yang ada sepanjang tahun dan Tabel 7 yang menunjukkan tingkat ketersediaan air oleh neraca air pada data eksisting padi sepanjang tahun.

\section{Manual Simulasi dengan Alternatif A Padi Sepanjang Tahun}

Simulasi yang dilakukan dengan data eksisting yang telah dihitung dengan neraca air di atas, melalui pendekatan keseimbangan air pada alternatif A, maka juga akan disimulasikan kadar air pemenuhan setiap bulan selama 50 tahun dengan metode manual. Dengan kebutuhan akan kemampuan pemenuhan air yang disesuaikan, menyediakan bendungan air. Dalam simulasi alternatif A digunakan kondisi inisial dengan memperhatikan hal-hal sebagai berikut:

a. Pasokan air ke perikanan mengikuti ketersediaan air dalam alternatif A. Pasokan air secara penuh dalam 2 bulan pertama dan 2 bulan dapat digunakan untuk budidaya udang.

b. Irigasi pada padi sepanjang tahun Alternatif A dipenuhi kebutuhan airnya di musim tanam I dari bulan November sampai Februari. Lalu mendapatkan setengah jatah 
pemenuhan air di musim tanam ke II dan III selama musim tanam.

c. Pada kebutuhan air domestik memiliki setengah jatah pemenuhan airnya pada Juli-September yang merupakan puncak musim kemarau.

d. Pemenuhan kebutuhan air industri diberi penuh dan dikurangi pada bulan April sampai Juni.

Dalam Alternatif A, data padi sepanjang tahun ini menggunakan data yang ada di lapangan sebagaimana terlihat pada Tabel 8 yang menunjukkan kebutuhan air di alternatif $\mathrm{A}$ peras sepanjang tahun.

\section{Simulasi manual data eksisting dengan perubahan pola penanaman Padi-Padi-Palawija}

Pemenuhan grafik air selama 50 tahun pada gambar di atas menunjukkan bahwa mayoritas musim kemarau yang berpengalaman dari bulan Juli sampai September, debit terkecil adalah $0,0 \mathrm{~m}^{3} / \mathrm{dtk}$ dan debit terbesarnya adalah $1560,1 \mathrm{~m}^{3} / \mathrm{dtk}$. Dengan kebutuhan akan kemampuan pemenuhan air yang disesuaikan, menyediakan bendungan air.

Simulasi dilakukan secara manual dengan mengubah tingkat pemenuhan air, yang berbeda dengan data yang ada yaitu mengubah pola padi sepanjang tahun menjadi pola tanaman padi-padian. Periode penanaman padi awal dilakukan pada bulan November, dan 4 bulan terakhir adalah bulan Juli, Agustus, September, Oktober dimana kekurangan air biasanya digunakan untuk penanaman tanaman. Pada Tabel 9 menunjukkan tingkat persediaan air oleh neraca air pada data pola tanam yang ada sepanjang tahun. Tabel 10 menunjukkan tingkat persediaan air oleh neraca air pada data pola tanam yang ada sepanjang tahun

\section{Simulasi secara manual menggunakan pola tanam padi padi-Palawija}

Simulasi dilakukan dengan data yang ada yang telah dihitung dengan neraca air di atas, melalui pendekatan water balance dan juga disimulasikan water level pemenuhan setiap bulan selama 50 tahun dengan metode manual. Dengan kebutuhan akan kemampuan pemenuhan air yang disesuaikan, menyediakan bendungan air. Dalam simulasi alternatif A digunakan kondisi inisial dengan memperhatikan hal-hal sebagai berikut:

a. Alternatif Perikanan disimulasikan menggunakan perikanan dengan jenis ikan patin dan lele dumbo yang menggunakan kebututuhan air tetap pada pemeliharaannya. Dan penambahan air yang dibuat untuk menggantikan air yang diuapkan sekitar $30 \%$ dari volume kolam 1 kali dan penggantian air kotor 1 kali juga. Jadi, pada alternatif ini diberikan air penuh dalam 2 bulan pertama, sebanyak setengahnya dalam dua bulan ke depan, maka tidak ada pasokan air dari bulan Mei sampai November.

b. Irigasi Alternatif pada Tanaman Padi Awal mulai dipenuhi air dari bulan November sampai Februari sebagai musim tanam pertama, kemudian mendapatkan alokasi air hanya setengahnya pada musim tanam kedua dari bulan Maret sampai Juni. Dan musim tanam ketiganya tumbuh atau kosong.

c. Pada kebutuhan air domestik dikurangi separuh kuota kebutuhannya saat mendekati musim kemarau pada bulan April sampai Juni saja.

d. Kebutuhan air industri untuk mendapatkan ransum penuh pada Januari sampai September dan setengah kuotanya pada bulan Oktober sampai Desember.

Dalam Alternatif A Padi-Padi-Palawija menggunakan data eksisting pada Tabel 11 yang menunjukkan kebutuhan air dalam pola tanam padi-palawija alt. A dan Tabel 12 yang menunjukkan tingkat persediaan air oleh neraca air pada pola tanam padi-padi-palawija alt.A

\section{Nilai Optimalisasi}

Setelah simulasi di atas dapat dilihat nilai optimalisasi masing-masing simulasi sehingga dapat disimulasikan lebih optimal untuk pemenuhan air oleh Bendung Gerak Sembayat. Berikut ini akan disajikan nilai perbandingan optimasi dalam beberapa tahun dengan beberapa defisit air bulan kering pada tabel 17 untuk neraca air tahun ke 2 terhadap data eksisting pola tanam padi sepanjang tahun, tabel 18 untuk neraca air tahun ke 2 pada alt. A padi sepanjang tahun, tabel 19 untuk data eksisting pola tanam padipadi-palawija, tabel 20 untuk alternatif A padi-padi-palawija, tabel 21 untuk data eksisting pola tanam padi-palawijapalawija dan tabel 22 untuk alternatif A padi-palawijapalawija

Dari tabel sampel neraca air pada tahun ke 2 masingmasing alternatif di atas dapat diketahui bahwa data padi sepanjang sahun memiliki kebutuhan air konstan dan besar, perubahan data pada pola pertanaman ditemukan bahwa kebutuhan airnya berfluktuasi dalam satu tahun, hal ini dipengaruhi oleh kebutuhan air irigasi yang bervariasi, dalam hal ini beras akan ditanam sepanjang tahun menjadi pola tanam padi-padi-palawija dan pola tanam padi-palawijapalawija. Kebutuhan air yang ada dan berdasarkan kemampuan air pada Bendung Gerak Sembayat, maka dapat ditentukan koefisien pemenuhannya bervariasi, seringkali tergantung debit inflow setiap bulannya, di akhir tampungan sebelum masa kering dan kebutuhan air setiap bulannya. 
Koefisien pemenuhan ini mengacu pada skala persentase kepatuhan sebesar 0\% $-100 \%$.

\section{Kriteria Optimalisasi}

Kriteria untuk optimalisasi simulasi ini adalah untuk melayani kebutuhan air maksimal dan mendapatkan persentase pemenuhan maksimal juga. Setelah melakukan ketiga simulasi diatas hasil optimal diperoleh sebagai berikut pada Tabel 23 yang menunjukkan total kebutuhan air dan persentase kepatuhan pada simulasi keenam. Dan juga ditunjukkan oleh Gambar 5 yang menunjukkan kebutuhan air untuk simulasi alternatif grafik keenam $\left(106 \mathrm{~m}^{3} /\right.$ bulan $)$. Dari Tabel 23 dapat dilihat grafik rata-rata kebutuhan air dan pemenuhan air 50 tahun pada masing-masing alternatif, bahwa Alternatif padi-palawija-palawija yang termasuk kuadran-1 yang memiliki nilai kebutuhan air yang besar dan persentase pemenuhan airnya tertinggi. Oleh karena itu, Neraca Air pada pola tanam data eksisting dari padi-palawija-palawija merupakan hasil optimal dari enam alternatif simulasi yang dilakukan.

\section{Simpulan}

Berdasarkan hasil di atas dapat disimpulkan bahwa:

1. Data debit Bendung Gerak Sembayat dapat dihasilkan dengan menggunakan metode Thomas Fiering sebanyak 50 tahun dengan terlebih dahulu menghilangkan debit kosong pada debit inflow yang ada.

2. Simulasi dilakukan untuk mendapatkan hasil optimal dalam mengetahui pola terbaik untuk memenuhi kebutuhan air Bendung Gerak Sembayat memiliki 6 simulasi.

3. Dari kesemua enam simulasi di atas, hasil simulasi yang diperoleh adalah grafik kuadran yang paling optimal ditunjukkan pada simulasi pola tanam padi-palawijapalawija yang terdapat pada Kuadran 1.

\section{Daftar Pustaka}

[1] M. Marselia, A. Sabar, I. R. S. Salami, and D. Marganingrum, "Model Prakiraan Debit Air dalam Rangka Optimalisasi Pengelolaan Waduk SagulingKaskade Citarum,” J. Tek. Sipil, vol. 24, no. 1, pp. 99108, 2017.

[2] D. N. Khaerudin, "Kajian Potensi Air dan Pengembangan Sumberdaya Air DAS Sembayat (Pengembangan Wilayah Utara Kabupaten Gresik)," Buana Sains, vol. 7, no. 1, pp. 33-42, 2007.

[3] A. A. Harms and T. H. Campbell, "An Extension to the Thomas-Fiering Model for the Sequential Generation of Streamflow," Water Resour. Res., vol. 3, no. 3, pp. 653-662, 1967.

[4] R. J. Kodoatie, Suharyanto, S. Sangkawati, and S. Edhisono, Pengelolaan Sumber Daya Air dalam Otonomi Daerah, Andi. Yogyakarta, 2002. 
Tabel 1. Jenis tabel dan jumlah air yang harus disuplai Bendung Gerak Sembayat

\begin{tabular}{|c|c|c|c|}
\hline No. & $\begin{array}{c}\text { Types of } \\
\text { Wrater } \\
\text { Requirement }\end{array}$ & Total & Lnit \\
\hline I & Irrigation & 20.933 & $\mathrm{~m}^{3} / \mathrm{s}$ \\
\hline 2 & Domestic & $\mathbf{2 . 4 1 1 4}$ & $\mathrm{m}^{3} / \mathrm{s}$ \\
\hline 3 & Industry & 5.6 & $\mathrm{~m}^{3} / \mathrm{s}$ \\
\hline 4 & Fishery & 19.175 & $\mathrm{~m}^{3} / \mathrm{s}$ \\
\hline $\begin{array}{l}\text { Total Winter } \\
\text { Requirement }\end{array}$ & 48.1 & $\mathrm{~m}^{3} / \mathrm{s}$ \\
\hline
\end{tabular}

Tabel 2. Debit bulanan Bendung Gerak Sembayat

\begin{tabular}{|c|c|c|c|c|c|c|c|c|c|c|c|c|}
\hline \multicolumn{13}{|c|}{ DATA DEBIT INFLOW BGS } \\
\hline Year & Jan. & Feb. & Mar. & Apr. & May & Jun. & Jul. & Aug. & Sep. & Oct. & Nov. & Dec. \\
\hline 1981 & 645.6 & 742.0 & 389.8 & 269.7 & 335.5 & 199.7 & 288.4 & 101.7 & 116.7 & 132.5 & 352.4 & 625.1 \\
\hline 1982 & $1,305.8$ & $1,378.6$ & $1,105.6$ & 721.5 & 124.2 & 67.9 & 34.4 & 36.4 & 29.1 & 25.2 & 34.6 & 294.4 \\
\hline 1983 & 807.8 & 821.0 & 746.9 & 691.0 & 844.7 & 225.8 & 79.0 & 62.6 & 54.7 & 122.9 & 525.6 & 498.1 \\
\hline 1984 & $1,166.0$ & $1,687.2$ & $1,044.7$ & 648.9 & 288.8 & 111.4 & 102.5 & 69.0 & 246.6 & 212.2 & 139.3 & 751.9 \\
\hline 1985 & 869.8 & $1,026.1$ & $1,143.2$ & 716.8 & 227.1 & 242.8 & 69.2 & 49.2 & 43.1 & 86.8 & 172.0 & 428.7 \\
\hline 1986 & 845.4 & $1,099.6$ & $1,147.8$ & $1,012.8$ & 145.4 & 288.0 & 128.4 & 45.3 & 94.7 & 96.3 & 331.5 & 248.4 \\
\hline 1987 & $1,037.4$ & $1,281.4$ & 830.3 & 200.1 & 104.9 & 109.7 & 37.4 & 20.7 & 16.0 & 13.0 & 65.0 & 558.0 \\
\hline 1988 & 649.9 & 899.7 & 727.1 & 334.5 & 298.3 & 111.4 & 35.0 & 28.6 & 18.9 & 42.2 & 335.8 & 427.5 \\
\hline 1989 & 806.9 & 978.9 & 704.2 & 539.3 & 339.2 & 625.2 & 263.3 & 72.7 & 31.6 & 44.3 & 199.5 & 386.3 \\
\hline 1990 & 892.4 & 788.7 & 586.6 & 332.5 & 218.8 & 93.6 & 77.0 & 31.5 & 27.1 & 30.6 & 54.2 & 618.9 \\
\hline 1991 & 890.3 & $1,015.0$ & 561.3 & 775.3 & 188.4 & 36.5 & 22.7 & 14.1 & 11.6 & 11.7 & 215.9 & 620.6 \\
\hline 1992 & 931.3 & $1,004.8$ & 848.2 & 845.4 & 243.4 & 201.9 & 38.2 & 53.7 & 235.5 & 116.7 & 323.5 & 793.3 \\
\hline 1993 & 981.3 & 977.5 & 730.7 & 884.7 & 193.3 & 206.8 & 40.8 & 20.3 & 19.5 & 18.8 & 152.6 & 472.0 \\
\hline 1994 & 769.6 & $1,036.9$ & $1,493.7$ & 666.5 & 113.4 & 18.0 & 7.6 & 3.6 & 1.6 & 3.3 & 222.8 & 286.5 \\
\hline 1995 & 406.7 & $1,187.5$ & $1,185.6$ & 668.8 & 203.7 & 300.9 & 92.5 & 13.9 & 8.3 & 112.1 & 635.0 & 814.0 \\
\hline 1996 & 581.9 & $1,099.3$ & 779.2 & 451.4 & 105.4 & 27.4 & 13.0 & 21.3 & 9.1 & 53.7 & 508.4 & 669.5 \\
\hline 1997 & 525.2 & 878.4 & 331.3 & 56.2 & 139.5 & 24.5 & 9.9 & 3.3 & $\cdot$ & $\because$ & 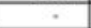 & 281.6 \\
\hline 1998 & 309.1 & $1,150.4$ & $1,255.0$ & 790.3 & 328.1 & 458.5 & 328.5 & 197.9 & 53.8 & 331.8 & 973.4 & 579.3 \\
\hline 1999 & $1,175.7$ & 902.0 & $1,052.4$ & 665.0 & 262.8 & 47.1 & 62.3 & 16.1 & 6.2 & 125.5 & 704.4 & 623.8 \\
\hline 2000 & 775.7 & 834.1 & 994.2 & 989.1 & 329.0 & 109.9 & 38.3 & 28.5 & 41.3 & 173.3 & 297.2 & 179.6 \\
\hline 2001 & 879.0 & 926.3 & $1,087.2$ & 801.7 & 180.8 & 368.2 & 75.3 & 18.6 & 16.0 & 182.1 & 157.8 & 102.9 \\
\hline 2002 & 731.4 & 715.5 & 775.6 & 500.3 & 73.2 & 24.9 & 9.2 & 3.7 & 1.3 & 1.0 & 64.2 & 589.6 \\
\hline 2003 & 820.7 & $1,359.6$ & 873.7 & 193.8 & 147.4 & 40.4 & 71.8 & 3.8 & 3.5 & 10.7 & 434.0 & 337.3 \\
\hline 2004 & 951.3 & 832.0 & $1,044.8$ & 331.3 & 111.7 & 51.1 & 39.9 & 18.2 & 2.3 & 2.0 & 184.1 & 672.9 \\
\hline
\end{tabular}

Tabel 3. Nilai koefisien regresi bulanan

\begin{tabular}{|l|l|l|l|l|l|l|l|l|l|l|l|l|}
\hline Simp Baku (Sd) & 233.04353 & 229.22389 & 278.67415 & 263.64723 & 155.0169 & 154.9258 & 87.9052 & 42.24619 & 66.95786 & 83.52598 & 237.65 & 197.0409 \\
\hline
\end{tabular} \begin{tabular}{|l|l|l|l|l|l|l|l|l|l|l|l|l|l|}
\hline Koef korelasi $(\mathrm{kb})$ & 0.2926005 & 0.3956704 & 0.5247913 & 0.1899588 & 0.352524 & 0.74142 & 0.85484 & 0.418123 & 0.474936 & 0.608951 & 0.285979 & 0.285979 \\
\hline
\end{tabular} \begin{tabular}{|l|l|l|l|l|l|l|l|l|l|l|l|l|l|l|}
\hline Koef Regresi (rb) & 0.2974762 & 0.2974762 & 0.3254594 & 0.5547024 & 0.323075 & 0.352732 & 1.30669 & 1.778727 & 0.263809 & 0.380728 & 0.214026 & 0.344918 \\
\hline
\end{tabular}

Tabel 4. Data Hasil Data Debit Perpanjangan selama 50 tahun

\begin{tabular}{|c|c|c|c|c|c|c|c|c|c|c|c|c|}
\hline \multicolumn{13}{|c|}{ Data Hasil Perpanjangan Data Debit (selama 50 tahun) Metode Thomas Fiering } \\
\hline Tahun ke - & Jan. & Feb. & Mar. & Apr. & May & Jun. & Jul. & Aug. & Sep. & Oct. & Nov. & Dec. \\
\hline 1 & 1196.2 & 804.5 & 996.3 & 1244.9 & 446.9 & 308.9 & 250.3 & 307.4 & 115.8 & 155.5 & 207.2 & 742.0 \\
\hline 2 & 676.6 & 1014.6 & 1250.1 & 862.5 & 161.3 & 27.5 & 4.0 & 6.5 & 22.0 & 45.5 & 249.7 & 691.0 \\
\hline 3 & 1086.3 & 531.6 & 567.2 & 127.7 & 2.7 & 175.3 & 28.5 & 12.4 & 37.0 & 174.8 & 708.4 & 555.0 \\
\hline 4 & 724.2 & 1170.3 & 1185.7 & 999.8 & 517.1 & 374.1 & 364.8 & 598.3 & 110.7 & 151.7 & 399.1 & 936.0 \\
\hline 5 & 865.0 & 1096.2 & 613.1 & 553.8 & 140.2 & 1.6 & 3.0 & 31.6 & 12.8 & 69.1 & 90.8 & 486.1 \\
\hline 6 & 641.4 & 1058.7 & 910.3 & 703.5 & 410.1 & 214.6 & 157.2 & 256.4 & 163.7 & 90.12519 & 408.0 & 685.0 \\
\hline 7 & 901.1 & 781.6 & 679.0 & 278.5 & 65.1 & 173.8 & 178.6 & 206.6 & 40.7 & 34.9 & 292.5 & 308.3 \\
\hline 8 & 908.0 & 600.6 & 761.4 & 322.8 & 53.0 & 27.3 & 4.6 & 47.1 & 32.7 & 72.1 & 11.8 & 404.0 \\
\hline 9 & 959.6 & 1172.1 & 1249.1 & 735.1 & 215.0 & 60.4 & 79.0 & 5.0 & 68.0 & 17.6 & 39.7 & 366.8 \\
\hline 10 & 656.0 & 975.3 & 871.9 & 898.1 & 46.0 & 3.5 & .153 .0 & -337.9 & -95.4 & 34.6 & 296.7 & -72.7 \\
\hline 11 & 590.0 & 1113.4 & 1218.6 & 733.9 & 343.4 & 256.6 & 229.1 & 347.1 & 87.1 & 151.5 & 106.4 & 804.1 \\
\hline 12 & 860.2 & 774.5 & 908.5 & 1121.5 & 457.5 & 345.2 & 321.0 & 446.8 & 166.4 & 213.5 & 384.7 & 149.1 \\
\hline 13 & 765.8 & 929.2 & 773.4 & 763.2 & 552.0 & 193.3 & 86.4 & 66.7 & 115.8 & 28.3 & 418.5 & 495.4 \\
\hline 14 & 727.0 & 820.2 & 859.5 & 130.9 & 46.0 & 192.1 & 62.2 & 87.5 & 48.7 & 129.0 & 77.5 & 737.3 \\
\hline 15 & 1027.4 & 946.3 & 721.6 & 561.0 & 277.9 & 1.4 & 24.3 & 15.3 & 17.8 & 158.1 & 507.9 & 833.5 \\
\hline 16 & 772.6 & 1112.6 & 574.3 & 218.1 & 69.6 & 52.1 & 23.9 & 32.0 & 22.4 & 25.4 & 236.0 & 424.0 \\
\hline 17 & 668.9 & 1076.3 & 904.1 & 474.6 & 195.5 & 169.2 & 186,3 & 218.1 & 92.4 & 48.5 & 460.6 & 571.5 \\
\hline 18 & 1259.7 & 1132.1 & 663.0 & 710.7 & 479.0 & 154.7 & 73.9 & 33.9 & 21.1 & 142.0 & 147.9 & 782.7 \\
\hline 19 & 507.2 & 654.2 & 627.1 & 712.7 & 528.9 & 257.9 & 246.2 & 334.8 & 191.7 & 1.9 & 458.9 & 563.0 \\
\hline 20 & 1089.8 & 914.1 & 773.2 & 699.9 & 465.5 & 1.1 & 4.0 & 22.9 & 12.6 & 57.8 & 350.3 & 762.8 \\
\hline 21 & 1057.3 & 1285.6 & 1361.7 & 906.1 & 213.9 & 308.7 & 338.6 & 578.2 & 255.1 & 144.4 & 396.7 & 556.5 \\
\hline 22 & 776.5 & 847.2 & 961.0 & 544.2 & 122.3 & 120.7 & 18.3 & 12.5 & 88.7 & 91.3 & 257.4 & 420.1 \\
\hline 23 & 516.3 & 1081.9 & 1131.0 & 630.8 & 152.2 & 235.6 & 129.5 & 168.6 & 46.2 & 146.9 & 87.5 & 199.7 \\
\hline 24 & 797.4 & 1065.6 & 1070.3 & 774.9 & 186.6 & 66.0 & 32.7 & 23.6 & 0.7 & 63.9 & 300.1 & 496.8 \\
\hline
\end{tabular}


Tabel 5. Perhitungan Saldo Air tahun 1,2, dan 3

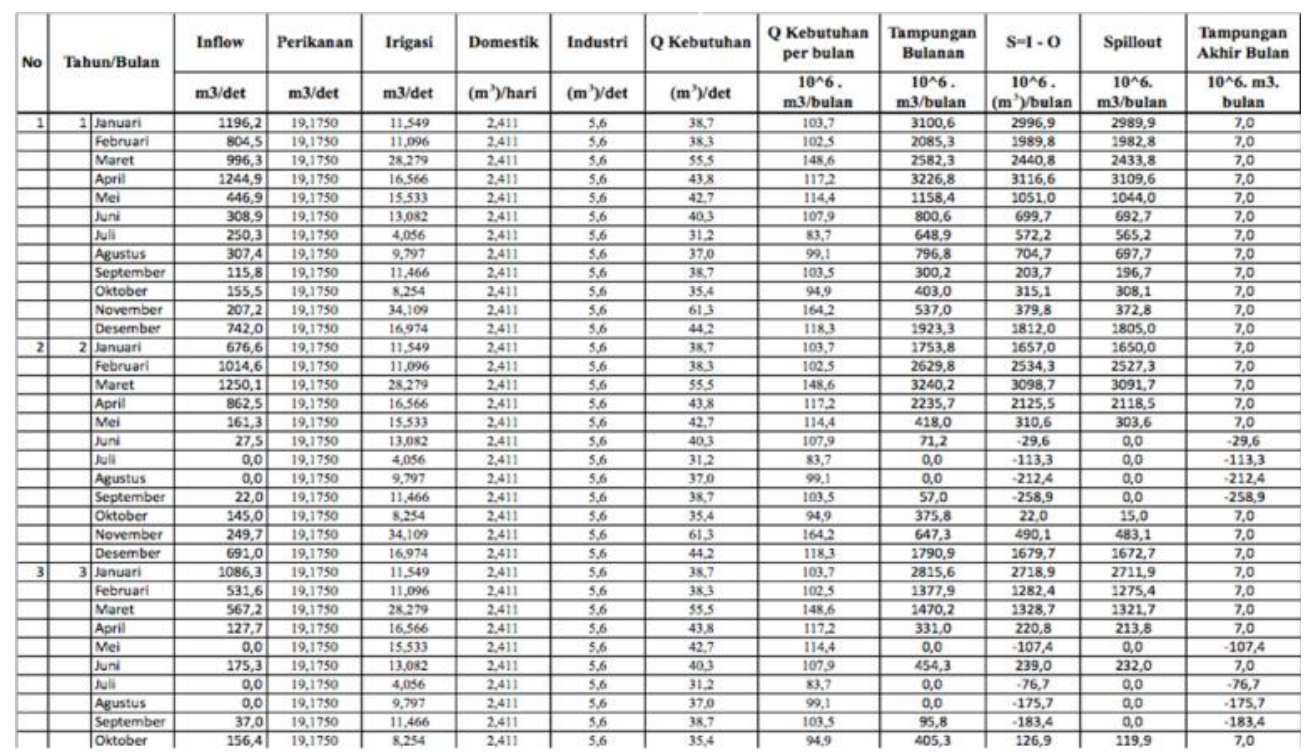

Tabel 6. Permintaan air pada data yang ada Beras Sepanjang Tahun

\begin{tabular}{cccc} 
Perikanan & Irigasi & Domestik & Industri \\
\hline$\left(\mathrm{m}^{3}\right) / \mathrm{s}$ & $\left(\mathrm{m}^{3}\right) / \mathrm{s}$ & $\left(\mathrm{m}^{3}\right) / \mathrm{s}$ & $\left(\mathrm{m}^{3}\right) / \mathrm{s}$ \\
19,175 & 20,933 & 2,411 & 5,6 \\
\hline
\end{tabular}

Tabel 7. Tingkat persediaan air oleh Saldo Air pada data yang ada Beras Sepanjang Tahun

\begin{tabular}{|c|c|c|c|c|c|c|c|c|c|c|c|c|c|}
\hline $\mathrm{Na}$ & Tahun'Bulan & In:10\% & Perlimar & Irigasi & Domestik & IJdustr] & Q Kebutuhan & $\begin{array}{c}\text { Q Kejutuhan } \\
\text { per bulaz }\end{array}$ & $\begin{array}{c}\text { Tanpungm } \\
\text { Bulanm }\end{array}$ & $S=I-0$ & Spllout & $\begin{array}{l}\text { Tampungas } \\
\text { Asthir Bulas. }\end{array}$ & $\begin{array}{c}\% \\
\text { pemenutan }\end{array}$ \\
\hline & & $\mathrm{m} 3 / \mathrm{set}$ & $\mathrm{m} 3 / \mathrm{dct}$ & $\mathbf{m} \mathbf{3}^{3}$ /det & $\left(\mathrm{m}^{3}\right)^{3} \mathrm{hat}$ & (n't)'idct & $\left(m^{3}\right)^{\prime} d c t$ & $\begin{array}{c}10 \wedge 6 . \\
\text { míbulac }\end{array}$ & $\begin{array}{c}10 \wedge 6 . \\
\text { môbulan }\end{array}$ & $\begin{array}{c}10^{\wedge} 6 . \\
\left(m^{3}\right) \text { bulan }\end{array}$ & $\begin{array}{c}10^{\prime} 6 . \\
\mathrm{m}^{2}, \mathrm{bulan}\end{array}$ & $\begin{array}{c}10^{1} 6 . \mathrm{m} 3 . \\
\text { bulan }\end{array}$ & $\%$ \\
\hline 1 & 1 Januari & 1196,2 & $15,13 \mathrm{C}$ & $1: 549$ & 2,411 & 5,5 & 38,7 & lC: $; 7$ & $3: x, E$ & $299 E, 9$ & 2989,3 & 7.0 & 1,00 \\
\hline & elbruań & 34,5 & 15,135 & 1:-095 & 2,411 & 5,5 & 38,3 & 1C:5,5 & 2035,3 & 1935,8 & 1982,3 & 7.0 & 1,00 \\
\hline & Mret & 996,3 & 15,135 & $4,6 \pm 1$ & 2,411 & 5,5 & 31,9 & 35,4 & 2532,3 & 2534,0 & 2497,0 & 7.0 & 1,00 \\
\hline & spri & 124,5 & 15,1780 & 8,090 & 2,411 & 5,5 & 39,2 & 94,3 & $322 c, E$ & $3: 35,5$ & $3.32,5$ & 7.0 & 1,00 \\
\hline & Mai & $\$ 46,9$ & 15,135 & 7,557 & 2,411 & 5,5 & 34,7 & 22,9 & 1:5\%,4 & 1072,5 & 1065,5 & 7.0 & 1,00 \\
\hline & Ju1i & $x B, 9$ & $15,13 x$ & 4,815 & 2,411 & 5,5 & 32,3 & 35,7 & 800,6 & 721,9 & 7149 & 7.0 & 1,00 \\
\hline & Jui & 250,3 & $15,175 \mathrm{C}$ & 4,056 & 2,411 & 5,5 & 31,2 & 33,7 & $5<8,9$ & 572,2 & $5 \in 5,2$ & 7.0 & 1,00 \\
\hline & DEutitus & 87,6 & 18,178 & 9,797 & 7,411 & 5,5 & 77,1 & $m .1$ & 706,8 & $m 4.7$ & $\approx i, 7$ & 70 & 1,00 \\
\hline & September & 215,8 & 15,135 & $1:-465$ & 2,411 & 5,5 & 38,7 & 1C:5 & 300,2 & 203,7 & 196,7 & 7.0 & 1,00 \\
\hline & Oktober & 155,5 & $15,175 \mathrm{C}$ & 3,254 & 2,411 & 5,5 & 35,4 & 94,9 & 403,0 & $315,-$ & 308,1 & 7.0 & 1,00 \\
\hline & Voyerite: & $x i, \bar{z}$ & 15,135 & 34,109 & 2,411 & 5,5 & 61,3 & $1 \leqslant 2$ & 557.0 & 399.8 & 3728 & 7.0 & 1,00 \\
\hline & Sesenber & 742,0 & 15,125 & 16,974 & 2,411 & 5,5 & 44,2 & $11 \varepsilon, 3$ & 1923,3 & 1812,0 & 1805,0 & 7.0 & 1,00 \\
\hline 2 & 2 Januari & 276,6 & 15,135 & $1: 5<9$ & 2,411 & 5,5 & 38,7 & 1C:3 & $17,3, \mathrm{E}$ & 1657,0 & 1652,0 & 7.0 & 1,00 \\
\hline & etebruari & $101<, E$ & $15,13 \mathrm{X}$ & $1: 596$ & $2,41 !$ & 5,5 & 38,3 & 16.5 & $262 \mathrm{SE}, \mathrm{E}$ & 2539,3 & 2527,3 & 7.0 & 1,00 \\
\hline & Mret & 1250,1 & 15,135 & 4,631 & 2,411 & 5,5 & 31,9 & 35,4 & $324 C, 2$ & $3: 51,9$ & E:54,9 & 7.0 & 1,00 \\
\hline & Ppri & 362,5 & $15,175 \mathrm{C}$ & 8,030 & 2,411 & 5,5 & 35,2 & 94,3 & 2235,7 & $2: 42,3$ & $2: 41,3$ & 7.0 & 1,00 \\
\hline & Mei & $1 \in 1,3$ & $15,178 \mathrm{C}$ & 7,57 & 2,411 & 5,5 & 34,7 & 92,9 & 418,0 & $302:-$ & 325,1 & 7.0 & 1,00 \\
\hline & Juni & 20,5 & $15,135 \mathrm{C}$ & 4,815 & 2,411 & 5,5 & 32,3 & 35,7 & 71,2 & $.7,5$ & 0,3 & $-7,5$ & 0,83 \\
\hline & Jui & 0,0 & 15,135 & 4,056 & 2,411 & 5,5 & 31,2 & 33,7 & {$[0,0$} & $-31 \overline{2}$ & 0,3 & 51.2 & 0,00 \\
\hline & Pquítus & 0,0 & $15,135 \mathrm{C}$ & 9,797 & 2,411 & 5,5 & 37,3 & 9.1 & {$[0,0$} & $-190,2$ & 0,3 & $.190,2$ & 0,00 \\
\hline & September & 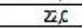 & $15,178 \mathrm{C}$ & 11,466 & $2,41 !$ & 5,5 & 38,7 & 1C:5 & 57,0 & $-236,7$ & 0,3 & $.236,7$ & 0,55 \\
\hline & Oklober & 145,0 & $15,138 \mathrm{C}$ & 8,254 & 2,411 & 5,5 & 35,4 & 94,9 & 375,8 & 4,2 & 37,2 & 7.0 & 1,00 \\
\hline & Toverite: & 299,7 & 15,135 & 34,109 & 2,411 & 5,5 & 61,3 & $1 \leqslant 2$ & $6<7,3$ & $400:-$ & 483,1 & 7.0 & 1,00 \\
\hline & Jesenber & $\$ 1,0$ & 15,135 & $16,5 ? 4$ & 2,411 & 5,5 & 44,2 & 115,3 & $17 x, 5$ & 1675,7 & 16727 & 7.0 & 1,00 \\
\hline 3 & 3 Jaxuari & 1085,3 & $15,173 \mathrm{C}$ & $1: 5<9$ & 2,411 & 5,5 & 38,7 & IC: 7 & $28 \mathrm{LE}, \mathrm{E}$ & $271 E, 9$ & 2711,9 & 7.0 & 1,00 \\
\hline & -etruan & 2011,6 & $15,1 / \mathrm{x}$ & 1. 1.46 & 2,411 & 2,3 & $5 \mathrm{k}, 5$ & ILs & $13 / 1,4$ & 1252,4 & $12 / 2,4$ & 8.0 & 1,00 \\
\hline & Mret & $\pi 7, \overline{2}$ & $15,13 \mathrm{C}$ & 4,631 & 2,411 & 5,5 & 31,7 & 35,4 & $14 \pi C, 2$ & 1391,9 & 1384,9 & 7.0 & 1,00 \\
\hline & Apri & 123,7 & 19,135 & 8,030 & 2,411 & 5,5 & 35,2 & 94,3 & 331,0 & $2<3,7$ & 236,7 & 7.0 & 1,00 \\
\hline & $M_{2 i}$ & 0,0 & $15,135 \mathrm{C}$ & 7,53 & 2,411 & 5,5 & 34,7 & 92,9 & 0,0 & $.35, c$ & 0,0 & .85 .9 & 0,00 \\
\hline & IInרi & $175, \overline{3}$ & 18.178 & 4.815 & 7.411 & 5,5 & 77.7 & 35.7 & 64,3 & $\$ 2,6$ & 75,6 & 70 & 1,00 \\
\hline & Jui & 0,0 & $15,135 \mathrm{C}$ & 4,056 & 2,411 & 5,5 & 31,2 & 33,7 & 0,0 & $-x E, \overline{7}$ & 0,3 & .76 .7 & 0,00 \\
\hline & Pguatus & 0,0 & $15,135 \mathrm{C}$ & 9,777 & 2,411 & 5,5 & 37,3 & 9.1 & 6,0 & $-175,7$ & 0,3 & $.175,7$ & 0,00 \\
\hline & September & $37 x$ & 15,138 & $1:, 466$ & 2,411 & 5,5 & 38,7 & $16: 5$ & 95,8 & $-183,4$ & 0,3 & $.133,4$ & 0,93 \\
\hline & Oktober & 56,4 & $15,178 \mathrm{C}$ & 8,234 & 2,411 & 5,5 & 35,4 & 94,9 & 405,3 & $\bar{L} 6.9$ & 119,9 & 7.0 & 1,00 \\
\hline
\end{tabular}


Tabel 8. Permintaan air pada alternatif A Beras Sepanjang Tahun

\begin{tabular}{cccc}
\hline No. & Tipe Kebutuhan Air & Total & Unit \\
\hline 1 & Irigasi & 20,933 & $\mathrm{~m}^{3} / \mathrm{det}$ \\
2 & Domestik & 2,4114 & $\mathrm{~m}^{3} / \mathrm{det}$ \\
3 & Industri & 5,6 & $\mathrm{~m}^{3} / \mathrm{det}$ \\
4 & Perikanan & 19,175 & $\mathrm{~m}^{3} / \mathrm{det}$ \\
& Total kebutuhan air & 48,1 & $\mathrm{~m}^{3} / \mathrm{det}$ \\
\hline
\end{tabular}

Tabel 9. Kebutuhan air pada data pola tanam padi-palawija yang ada

\begin{tabular}{cccc}
\hline No. Tipe Kebutuhan Air & Total & Unit \\
\hline & & 11,549 & $\mathrm{~m}^{3} / \mathrm{s}$ \\
& 11,096 & $\mathrm{~m}^{3} / \mathrm{s}$ \\
& & 28,279 & $\mathrm{~m}^{3} / \mathrm{s}$ \\
& & 16,566 & $\mathrm{~m}^{3} / \mathrm{s}$ \\
1 & Irigasi & 15,533 & $\mathrm{~m}^{3} / \mathrm{s}$ \\
& & 13,082 & $\mathrm{~m}^{3} / \mathrm{s}$ \\
& & 4,056 & $\mathrm{~m}^{3} / \mathrm{s}$ \\
& & 9,797 & $\mathrm{~m}^{3} / \mathrm{s}$ \\
& & 11,466 & $\mathrm{~m}^{3} / \mathrm{s}$ \\
& & 8,254 & $\mathrm{~m}^{3} / \mathrm{s}$ \\
4 & & 34,109 & $\mathrm{~m}^{3} / \mathrm{s}$ \\
4 & & 16,974 & $\mathrm{~m}^{3} / \mathrm{s}$ \\
& & 2,41 & $\mathrm{~m}^{3} / \mathrm{s}$ \\
& Domestic & 5,60 & $\mathrm{~m}^{3} / \mathrm{s}$ \\
& Industri & 19,18 & $\mathrm{~m}^{3} / \mathrm{s}$ \\
\hline
\end{tabular}

Tabel 10. Tingkat persediaan air oleh Saldo Air Data Ada pada pola penanaman Padi-Padi-Palawija

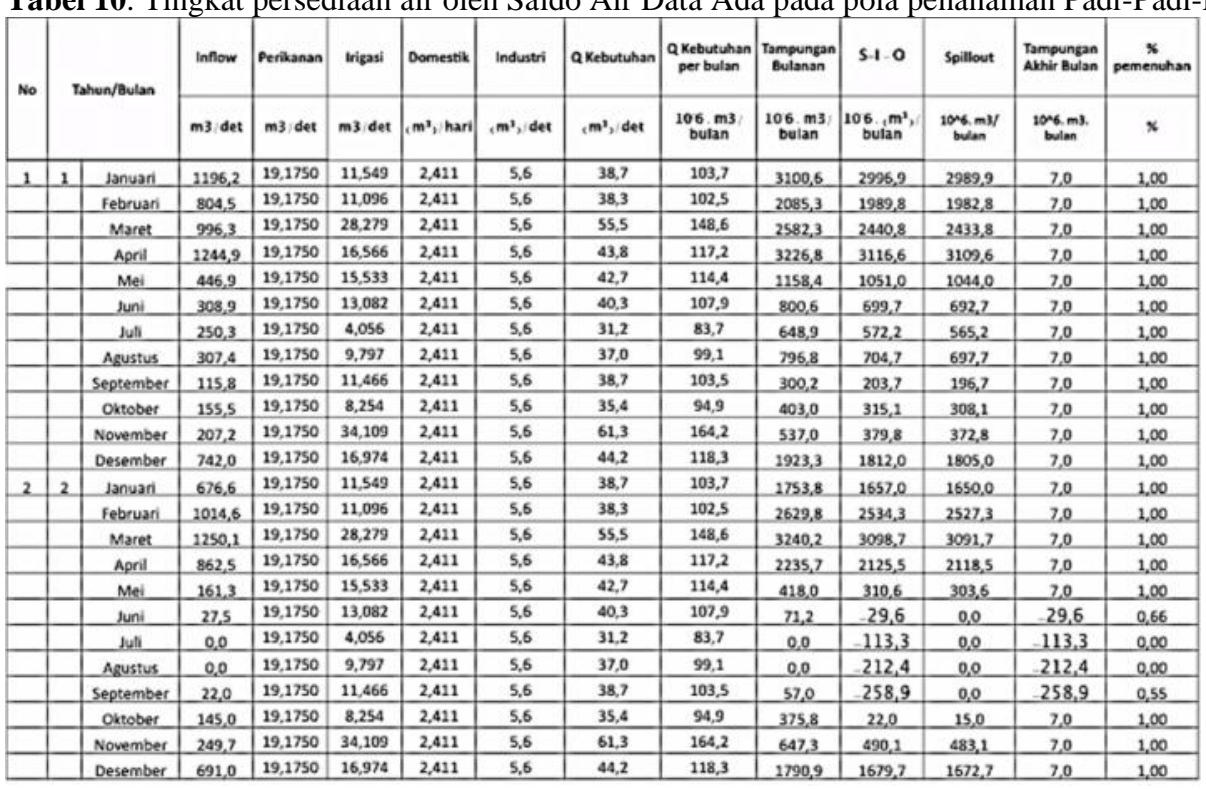


Tabel 11. Kebutuhan air dalam pola tanam padi-Palawija alt. A

\begin{tabular}{ccccc}
\hline Bulan & Perikanan & Irigasi & Domestik & Industri \\
\hline Januari & 1 & 1 & 1 & 1 \\
Februari & 1 & 1 & 1 & 1 \\
Maret & 0,5 & 0,5 & 1 & 1 \\
April & 0,5 & 0,5 & 0,5 & 1 \\
Mei & 0 & 0,5 & 0,5 & 1 \\
Juni & 0 & 0,5 & 0,5 & 1 \\
Juli & 0 & 0 & 1 & 1 \\
Agustus & 0 & 0 & 1 & 1 \\
September & 0 & 0 & 1 & 1 \\
Oktober & 0 & 0 & 1 & 0,5 \\
November & 1 & 1 & 1 & 0,5 \\
Desember & 1 & 1 & 1 & 0,5 \\
\hline
\end{tabular}

Tabel 12. Tingkat persediaan air oleh Saldo Air pada pola penanaman Padi-Padi-Palawija Alt.A

\begin{tabular}{|c|c|c|c|c|c|c|c|c|c|c|c|c|}
\hline \multirow{2}{*}{ ho } & \multirow{2}{*}{ Easen Yulas } & Ielkra & Mrscaue & Ines: & Dunatis & Indain & (0 Keaunata & $\begin{array}{l}\text { ONkastuturs } \\
\text { per terian }\end{array}$ & 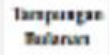 & $3-4-0$ & Splbsal & $\begin{array}{l}\text { Tamporesen } \\
\text { Aztir halss }\end{array}$ \\
\hline & & nitet & mistet & asidet & (a') & (n') tet & $\left(\mathbf{a}^{\prime}\right)$ atet & $\begin{array}{c}\text { 1Wh. } \\
\text { nituian }\end{array}$ & $\begin{array}{c}\text { 10x. } \\
\text { natritin }\end{array}$ & $\begin{array}{c}10 \% \text {. } \\
\text { ire'tyatas }\end{array}$ & $\begin{array}{c}\text { 11'k } \\
\text { nithatan }\end{array}$ & $\begin{array}{c}10 \times 6.61 . \\
\text { belse }\end{array}$ \\
\hline \multirow[t]{12}{*}{3} & .nst & 11542 & 8,93 & 155 & $A A$ & 58 & 69 & ब. & उदास $\mathrm{t}$ & 8569 & $89 \times 9$ & 30 \\
\hline & $\operatorname{letn} x$ & $\overline{a \times n}$ & रू(श) & 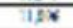 & $2 \pi 1$ & 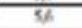 & ह5: & 705 & xos: & क्सर: & 1662,3 & 96 \\
\hline & Nert & $x$ & $\operatorname{sen} 2$ & 314 & 2A1 & 36 & 52 & $s 0$ & 2021 & $2 \times 4$ & 2292,3 & 30 \\
\hline & $l_{4}$ & Ex:5 & 485 & राख़ा & 15 & 56 & $\pi$ & 161 & 2365 & 865 & दाधा? & 31 \\
\hline & Nar & 462 & $c x x$ & 7,757 & $12 x$ & 56 & 105 & $2 \% 0$ & III: 4 & म12:4 & IIEA & 98 \\
\hline & $\ldots$ & $x \in 6$ & $6 x x$ & Sa1 & $1,3 x$ & 56 & 133 & 357 & 595 & $7 n 4.3$ & 348 & 70 \\
\hline & .21 & $2 \pi, 3$ & $6 x x$ & $\mathrm{mx}$ & क्रा & 56 & $\omega$ & 215 & हार & ma & हा? & 35 \\
\hline & syatn & $\sin 2$ & $0 x$ & $\omega x$ & 241 & 5 & $\omega$ & 7.s. & $m$, & 192,4 & ins & $3 \mathrm{~B}$ \\
\hline & 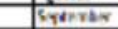 & $115 x$ & $6 x$ & vix & al & 5 & y & 55 & स्रु? & म्रक्य & $2 \times x$ & 3 \\
\hline & Cossege & E:2 & $\omega x$ & $2 x$ & 2ता! & 21 & 9 & 140 & दहE & 2580 & $2 \geq 0$ & 70 \\
\hline & Whotrits & $x=2$ & 8.193 & $3: 1 x$ & 211 & 28 & 35 & (6) & 5928 & 373 & 350.3 & 78 \\
\hline & Derefter & एक & ग(19) & कबत & 2,111 & 23 & 24 & 25 & $5 \operatorname{sen} 3$ & Eu25 & L2:2,5 & 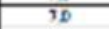 \\
\hline \multirow[t]{12}{*}{3} & $2 \ldots$ & sats & $\operatorname{sen}$ & iss & 241 & wa & 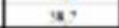 & $\cos 7$ & $10 \%$ & 6038 & 16029 & 30 \\
\hline & Atax & $\operatorname{tin} x$ & 8.18 & 118 & जा & con & 53 & 60 & 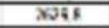 & 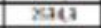 & 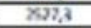 & 35 \\
\hline & Neni & 표:1 & $24 x$ & 214 & 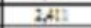 & 500 & 29 & 50 & $20: 2$ & 21522 & $215: 2$ & 78 \\
\hline & lia & 325 & 9,8 & 203 & $1,3 x$ & 50 & 15 & 161 & 20353 & 27366 & 21525 & 78 \\
\hline & Nix & 213 & $\sqrt{x}$ & क्षका & 1,13 & 50 & 116 & 720 & C2: & 3040 & $2 \times \rho 0$ & 90 \\
\hline & 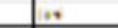 & $m$ & as & Avar & 1,30 & wa & 114 & 47 & $n$ & 05 & 5,3 & in \\
\hline & 31 & 5 & $a x$ & $a x$ & 311 & cona & w & 78 & 21 & 115 & $\mathrm{ma}$ & 115 \\
\hline & Fatals & 50 & $2 x$ & $\alpha x$ & 2.11 & 50 & $x$ & 213 & 22 & sII & 6 & II: \\
\hline & Enderas & $22:$ & ax & $a x$ & 211 & 50 & $y$ & 215 & $5 \%$ & $\theta$ & $\infty$ & 21 \\
\hline & Cdzhr & VSD & $\operatorname{sex}$ & $\alpha x$ & $2 \pi 11$ & 260 & $\$$ & 10 & 15र & 215,5 & 20,5 & 90 \\
\hline & nowertar & $x \in \gamma$ & $\mathrm{neys}$ & $\mathrm{sin}$ & zAil & $x=0$ & $\omega$ & is & 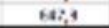 & $44: 5$ & $\operatorname{ces}$ & $i b$ \\
\hline & naskint & का & काश & बर्त & 2 ता & twa & 48 & Thx & 1त: 8 & 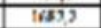 & tax? & 31 \\
\hline \multirow[t]{10}{*}{ 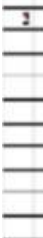 } & 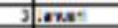 & 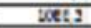 & 2,19 & 195 & 2,11 & 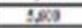 & 39 & 20,7 & 20.9! & $\operatorname{sen} 25$ & 2013 & 78 \\
\hline & Atovi & ज्ञा6 & $8.1 \%$ & 184 & 211 & tya & 83 & est & 1395 & 0528 & 1254 & 75 \\
\hline & NNi & 2032 & 96 & $x, 18$ & 2था & 120 & 2.9 & 150 & $25: 3$ & 4522 & पाइ,2 & 90 \\
\hline & 40 & $\operatorname{ton}, \gamma$ & x.e & Nes & 1,30 & wa & 7. & $\rightarrow 1$ & $+41,3$ & $m_{4}$ & $x<0$ & 18 \\
\hline & Nex & क & $\frac{j x}{x}$ & $2 \pi$ & $1, x$ & tera & 115 & 280 & Q1 & 58 & $\mathrm{Q}$ & का० \\
\hline & 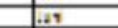 & L:S & $w x$ & 84 & $1.2 x$ & 150 & IS & 2.7 & 4A3 & 205 & $2 m 5$ & 38 \\
\hline & 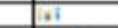 & m & $\mathrm{gx}$ & $\mathrm{gx}$ & 211 & $\operatorname{tg}$ & 3 & 25 & a) & 115 & $m$ & 115 \\
\hline & 2 antas & 50 & $2 x$ & $a x$ & 2ताt & 500 & 4 & 25 & 22 & 355 & 0,0 & $35 \mathrm{~s}$ \\
\hline & syexty & 02 & as & $i v=$ & Ait & wa & $x$ & $=3$ & 50 & 405 & 41,3 & in \\
\hline & Carner & 102 & wx & $x_{x}$ & 2,41 & tya & क्र & 160 & 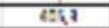 & कारु & गมा, & 70 \\
\hline
\end{tabular}


Tabel 13. Kebutuhan air pada data eksisting pola tanam padi-palawija-palawija

\begin{tabular}{cccc} 
No. & $\begin{array}{c}\text { Types of Water } \\
\text { Requirement }\end{array}$ & Total & Unit \\
\hline & & 11,549 & \\
& & 11,096 & \\
& & 4,681 & \\
& & 8,03 & \\
& & 7,507 & \\
1 & & 4,815 & \\
& Irrigation & 4,056 & \\
& & 9,797 & $\mathrm{~m}^{3} / \mathrm{dtk}$ \\
& & 11,466 & \\
& & 8,254 & \\
& & 34,109 & \\
3 & & 16,974 & \\
4 & & 2,41 & \\
\hline
\end{tabular}

Tabel 14. Neraca Air dan pemenuhan Air Data yang ada dengan pola tanam padi-palawija-palawija

\begin{tabular}{|c|c|c|c|c|c|c|c|c|c|c|c|c|c|}
\hline \multirow{2}{*}{ No } & \multirow{2}{*}{ Tahun/Bulan } & Inflow & Perikanan & Irigasi & Domestik & Industri & Q Kebutuhan & $\begin{array}{l}\text { Q Kebutuhan } \\
\text { per bulan }\end{array}$ & $\begin{array}{c}\text { Tampungan } \\
\text { Bulanan }\end{array}$ & S-1. O & Spillout & $\begin{array}{l}\text { Tampungan } \\
\text { Akhir Bulan }\end{array}$ & $\begin{array}{c}\% \\
\text { pemenuhan }\end{array}$ \\
\hline & & m3 det & m3 det & $\mathrm{m} 3$ det & $\begin{array}{l}\mathrm{cm}^{3} \\
\text { hari }\end{array}$ & $\left(m^{3}\right)$ det & $\left(\mathrm{m}^{3}\right)$ det & $\begin{array}{c}106 \cdot \mathrm{m} 3 / \\
\text { bulan }\end{array}$ & $\begin{array}{c}106 \cdot \mathrm{m} 3 \\
\text { bulan }\end{array}$ & $\begin{array}{l}106 \\
m^{3} \\
\text { bulan }\end{array}$ & $\begin{array}{c}1006 . \mathrm{m} 3 / \\
\text { bulan }\end{array}$ & $\begin{array}{c}\text { 1026. } \mathrm{m} 3 \text {. } \\
\text { bulan }\end{array}$ & $\%$ \\
\hline \multirow[t]{12}{*}{1} & Januari & 1196,2 & 19,1750 & 11.549 & 2,411 & 5,6 & 38,7 & 103,7 & 3100,6 & 2996,9 & 2989,9 & 200 & 1,00 \\
\hline & Februari & 804,5 & 19,1750 & 11,096 & 2,411 & 5,6 & 38,3 & 102,5 & 2085,3 & 1989,8 & 1982,8 & 7.0 & 1,00 \\
\hline & Maret & 996,3 & 19,1750 & 4,681 & 2,411 & 5,6 & 31,9 & 85,4 & 2582,3 & 2504,0 & 2497,0 & 7,0 & 1,00 \\
\hline & April & 1244,9 & 19,1750 & 8,030 & 2,411 & 5,6 & 35,2 & 94,3 & 3226,8 & 3139,5 & 3132,5 & 7,0 & 1,00 \\
\hline & Mei & 446,9 & 19,1750 & 7,507 & 2,411 & 5,6 & 34,7 & 92,9 & 1158,4 & 1072,5 & 1065,5 & 7,0 & 1,00 \\
\hline & Juni & 308,9 & 19,1750 & 4,815 & 2,411 & 5,6 & 32,0 & 85,7 & 800,6 & 721,9 & 714,9 & 7,0 & 1,00 \\
\hline & Juli & 250,3 & 19,1750 & 4,056 & 2,411 & 5,6 & 31,2 & 83,7 & 648,9 & 572,2 & 565,2 & 7,0 & 1,00 \\
\hline & Agustus & 307,4 & 19,1750 & 9,797 & 2,411 & 5,6 & 37,0 & 99,1 & 796,8 & 704,7 & 697,7 & 2,0 & 1,00 \\
\hline & September & 115,8 & 19,1750 & 11,466 & 2,411 & 5,6 & 38,7 & 103,5 & 300,2 & 203,7 & 196,7 & 7,0 & 1,00 \\
\hline & Oktober & 155,5 & 19,1750 & 8.254 & 2,411 & 5,6 & 35,4 & 94,9 & 403,0 & 315,1 & 308,1 & 7,0 & 1,00 \\
\hline & November & 207,2 & 19,1750 & 34,109 & 2,411 & 5,6 & 61,3 & 164,2 & 537,0 & 379,8 & 372,8 & 7,0 & 1,00 \\
\hline & Desember & 742,0 & 19,1750 & 16,974 & 2,411 & 5,6 & 44,2 & 118,3 & 1923,3 & 1812,0 & 1805,0 & 7,0 & 1,00 \\
\hline \multirow[t]{12}{*}{2} & Januari & 676,6 & 19,1750 & 11,549 & 2,411 & 5,6 & 38,7 & 103,7 & 1753,8 & 1657,0 & 1650,0 & 7,0 & 1,00 \\
\hline & Februari & 1014,6 & 19,1750 & 11,096 & 2,411 & 5,6 & 38,3 & 102,5 & 2629,8 & 2534,3 & 2527,3 & 7,0 & 1,00 \\
\hline & Maret & 1250,1 & 19,1750 & 4,681 & 2,411 & 5,6 & 31,9 & 85,4 & 3240,2 & 3161,9 & 3154,9 & 7,0 & 1,00 \\
\hline & April & 862,5 & 19,1750 & 8,030 & 2,411 & 5,6 & 35,2 & 94,3 & 2235,7 & 2148,3 & 2141,3 & 7,0 & 1,00 \\
\hline & Mei & 161,3 & 19,1750 & 7,507 & 2,411 & 5,6 & 34,7 & 92,9 & 418,0 & 332,1 & 325,1 & 2.0 & 1,00 \\
\hline & Juni & 27,5 & 19,1750 & 4,815 & 2,411 & 5,6 & 32,0 & 85,7 & 71,2 & -7.5 & 0.0 & -7.5 & 0,83 \\
\hline & Juli & 0,0 & 19,1750 & 4,056 & 2,411 & 5,6 & 31,2 & 83,7 & 0,0 & $-91,2$ & 0,0 & $-91,2$ & 0,00 \\
\hline & Agustus & 0,0 & 19,1750 & 9,797 & 2,411 & 5,6 & 37,0 & 99,1 & 0,0 & $-190,2$ & 0,0 & $-190,2$ & 0,00 \\
\hline & September & 22,0 & 19,1750 & 11,466 & 2,411 & 5,6 & 38,7 & 103,5 & 57,0 & $-236,7$ & 0,0 & $-236,7$ & 0,55 \\
\hline & Oktober & 145,0 & 19,1750 & 8,254 & 2,411 & 5,6 & 35,4 & 94,9 & 375,8 & 44,2 & 37,2 & 7,0 & 1,00 \\
\hline & November & 249,7 & 19,1750 & 34,109 & 2,411 & 5,6 & 61,3 & 164,2 & 647,3 & 490,1 & 483,1 & 7,0 & 1,00 \\
\hline & Desember & 691,0 & 19,1750 & 16,974 & 2,411 & 5,6 & 44,2 & 118,3 & 1790,9 & 1679,7 & 1672,7 & 7,0 & 1,00 \\
\hline
\end{tabular}


Tabel 15. Kebutuhan air pada data pola tanam padi-palawija-palawija alt.A

\begin{tabular}{ccccc} 
Month & Fishery & Irrigation & Domestic & Industry \\
\hline January & 1 & 1 & 1 & 1 \\
February & 1 & 1 & 1 & 1 \\
March & 0 & 0,5 & 1 & 1 \\
April & 0 & 0,5 & 1 & 0,5 \\
May & 0 & 0,5 & 1 & 0,5 \\
June & 0 & 0,5 & 1 & 0,5 \\
July & 0 & 0 & 0,5 & 1 \\
August & 0 & 0 & 0,5 & 1 \\
September & 0 & 0 & 0,5 & 1 \\
October & 0 & 0 & 1 & 1 \\
November & 1 & 1 & 1 & 1 \\
December & 1 & 1 & 1 & 1 \\
\hline
\end{tabular}

Tabel 16. Tingkat persediaan air oleh Keseimbangan Air pada pola tanam padi-palawija-palawija Alt.A

\begin{tabular}{|c|c|c|c|c|c|c|c|c|c|c|c|c|c|c|}
\hline \multirow{2}{*}{ No } & \multirow{2}{*}{\multicolumn{2}{|c|}{ Tahun/Bulan }} & Inflow & Perikanan & Irigasi & Domestik & Industri & Q Kebutuhan & $\begin{array}{c}\text { Q Kebutuhan } \\
\text { per bulan }\end{array}$ & $\begin{array}{c}\text { Tampungan } \\
\text { Bulanan }\end{array}$ & S. 10 & Spillout & $\begin{array}{l}\text { Tampungan } \\
\text { Akhir Bulan }\end{array}$ & $\begin{array}{c}\% \\
\text { pemenuhan }\end{array}$ \\
\hline & & & m3 det & $\mathrm{m} 3 / \mathrm{det}$ & m3 det & $\begin{array}{l}\mathrm{c}^{3}{ }^{3}, \\
\text { hari }\end{array}$ & ( $\mathbf{m}^{3}$, det & ${ }_{(} m^{3}$, det & $\begin{array}{c}106 . \mathrm{m} 3 \\
\text { bulan }\end{array}$ & $\begin{array}{c}106 \cdot \mathrm{m}^{3} \\
\text { bulan }\end{array}$ & $\begin{array}{l}106 \\
m^{3} \\
\text { bulan }\end{array}$ & $\begin{array}{c}10^{\wedge} 6 . \mathrm{m} 3 / \\
\text { bulsn }\end{array}$ & $\begin{array}{c}10^{\wedge} 6 . \mathrm{m} 3 . \\
\text { bulan }\end{array}$ & $\%$ \\
\hline \multirow[t]{12}{*}{1} & 1 & Januari & 1196,22 & 19,18 & 11,5 & 2,41 & 5,60 & 38,74 & 103,75 & 3100,61 & 2996,86 & 2989,86 & 7,00 & 1,00 \\
\hline & & Februari & 804,52 & 19,18 & 11,1 & 2,41 & 5,60 & 38,28 & 102,54 & 2085,32 & 1989,78 & 1982,78 & 7,00 & 1,00 \\
\hline & & Maret & 996,26 & 0,00 & 2,3 & 2,41 & 5,60 & 10,35 & 27,73 & 2582,32 & 2561,59 & 2554,59 & 7,00 & 1,00 \\
\hline & & April & 1244,91 & 0,00 & 4,0 & 2,41 & 2,80 & 9,23 & 24,71 & 3226,80 & 3209,08 & 3202,08 & 7,00 & 1,00 \\
\hline & & Mei & 446,92 & 0,00 & 3,8 & 2,41 & 2,80 & 8,97 & 24,01 & 1158,42 & 1141,41 & 1134,41 & 7,00 & 1,00 \\
\hline & & Juni & 308,87 & 0,00 & 2,4 & 2,41 & 2,80 & 7,62 & 20,41 & 800,58 & 787,18 & 780,18 & 7,00 & 1,00 \\
\hline & & Juli & 250,33 & 0,00 & 0,0 & 1,21 & 5,60 & 6,81 & 18,23 & 648,86 & 637,63 & 630,63 & 7,00 & 1,00 \\
\hline & & Agustus & 307,41 & 0,00 & 0,0 & 1,21 & 5,60 & 6,81 & 18,23 & 796,80 & 785,57 & 778,57 & 7,00 & 1,00 \\
\hline & & September & 115,83 & 0,00 & 0,0 & 1,21 & 5,60 & 6,81 & 18,23 & 300,24 & 289,01 & 282,01 & 7,00 & 1,00 \\
\hline & & Oktober & 155,48 & 0,00 & 0,0 & 2,41 & 5,60 & 8,01 & 21,46 & 403,00 & 388,54 & 381,54 & 7,00 & 1,00 \\
\hline & & November & 207,18 & 19,18 & 34,1 & 2,41 & 5,60 & 61,30 & 164,17 & 537,02 & 379,84 & 372,84 & 7,00 & 1,00 \\
\hline & & Desember & 742,01 & 19,18 & 17,0 & 2,41 & 5,60 & 44,16 & 118,28 & 1923,30 & 1812,02 & 1805,02 & 7,00 & 1,00 \\
\hline \multirow[t]{12}{*}{2} & 2 & Januari & 676,60 & 19,18 & 11,55 & 2,41 & 5,60 & 38,74 & 103,75 & 1753,75 & 1657,00 & 1650,00 & 7,00 & 1,00 \\
\hline & & Februari & 1014,59 & 19,18 & 11,10 & 2,41 & 5,60 & 38,28 & 102,54 & 2629,81 & 2534,28 & 2527,28 & 7,00 & 1,00 \\
\hline & & Maret & 1250,09 & 0,00 & 2,34 & 2,41 & 5,60 & 10,35 & 27,73 & 3240,24 & 3219,51 & 3212,51 & 7,00 & 1,00 \\
\hline & & April & 862,53 & 0,00 & 4,02 & 2,41 & 2,80 & 9,23 & 24,71 & 2235,67 & 2217,96 & 2210,96 & 7,00 & 1,00 \\
\hline & & Mei & 161,28 & 0,00 & 3,75 & 2,41 & 2,80 & 8,97 & 24,01 & 418,04 & 401,03 & 394,03 & 7,00 & 1,00 \\
\hline & & Juni & 27,48 & 0,00 & 2,41 & 2,41 & 2,80 & 7,62 & 20,41 & 71,24 & 57,83 & 50,83 & 7,00 & 1,00 \\
\hline & & Juli & 0,00 & 0,00 & 0,00 & 1,21 & 5,60 & 6,81 & 18,23 & 0,00 & $-11,23$ & 0,00 & $-11,23$ & 0,00 \\
\hline & & Agustus & 0,00 & 0,00 & 0,00 & 1,21 & 5,60 & 6,81 & 18,23 & 0,00 & $-29,46$ & 0,00 & $-29,46$ & 0,00 \\
\hline & & September & 21,99 & 0,00 & 0,00 & 1,21 & 5,60 & 6,81 & 18,23 & 56,99 & 9,30 & 2,30 & 7,00 & 1,00 \\
\hline & & Oktober & 145,00 & 0,00 & 0,00 & 2,41 & 5,60 & 8,01 & 21,46 & 375,84 & 361,38 & 354,38 & 7,00 & 1,00 \\
\hline & & November & 249,74 & 19,18 & 34,11 & 2,41 & 5,60 & 61,30 & 164,17 & 647,32 & 490,15 & 483,15 & 7,00 & 1,00 \\
\hline & & Desember & 690,95 & 19,18 & 16,97 & 2,41 & 5,60 & 44,16 & 118,28 & 1790,95 & 1679,67 & 1672,67 & 7,00 & 1,00 \\
\hline
\end{tabular}

Tabel 17. Water Balance tahun ke-2 untuk data eksisting padi sepnajang tahun

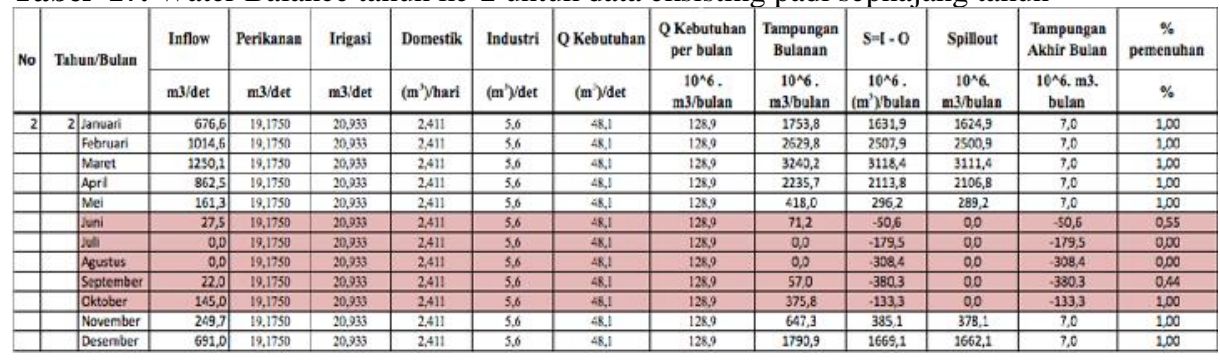


Tabel 18. Water Balance tahun ke-2 untuk alternative A padi sepanjang tahun

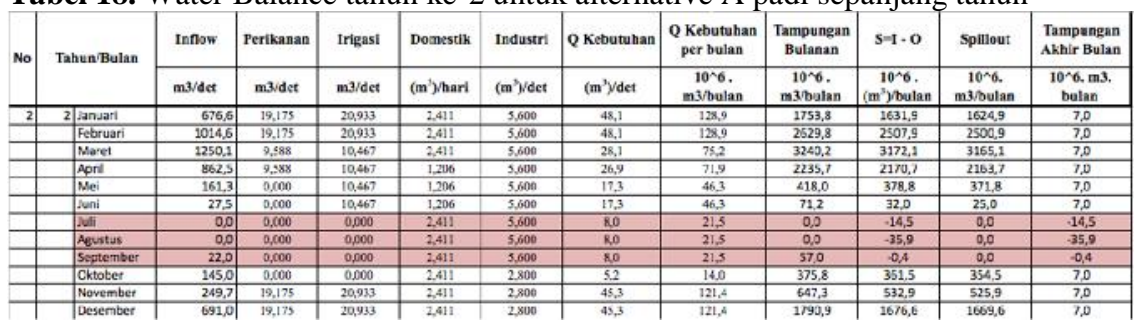

Tabel 19. Water Balance tahun ke-2 untuk data eksisting padi-padi-palawija

\begin{tabular}{|c|c|c|c|c|c|c|c|c|c|c|c|c|c|}
\hline & \multirow{3}{*}{ Tahun/Rulan } & \multirow{2}{*}{\multicolumn{2}{|c|}{\begin{tabular}{l|l|} 
Inffow & Perikanan
\end{tabular}}} & & & & & & & & & & \\
\hline & & & & Irigasi & Dometik & Industri & Q Kebstuthas & 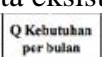 & $\underset{\substack{\text { Tampungan } \\
\text { Bulanana }}}{\text { and }}$ & $\mathrm{s}-1 \cdot 0$ & Spillout & Tampunzan & \% pemeaubas \\
\hline & & m33/det & m3/det & mis/det & (m) & (m) didet & ( $\left.\mathrm{m}^{2}\right)$ det & $\begin{array}{c}10^{106} \text {.6. } \\
\text { m3blas }\end{array}$ & $\begin{array}{c}1060.6 \\
\text { m3/bulas }\end{array}$ & & 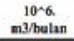 & & $\%$ \\
\hline & 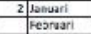 & & $\frac{19,19}{10,15}$ & $\frac{111,59}{11,0900}$ & 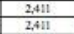 & & & & & & & & \\
\hline & $\underbrace{\text { Nert }}_{\text {Nerr }}$ & $\frac{12}{8}$ & 190.151 & $\frac{2227}{16.58}$ & & & & & & & & & \\
\hline & & $\frac{161}{212}$ & 17 & & $\frac{2}{2}$ & & & & & 310 & & & \\
\hline & & & & & & & & & & & & & \\
\hline & $\frac{A}{\text { Sestument }}$ & & 10,1300 & $\frac{5,9,77}{1,460}$ & $\frac{1.211}{2.1}$ & , & 3877 & & $\frac{570}{57,0}$ & $\frac{212,2}{.25 x}$ & $\frac{a b}{0,0}$ & $\frac{2.212,8}{258,9}$ & $\frac{0.00}{0.055}$ \\
\hline & $\begin{array}{l}\text { ofotese } \\
\text { Never }\end{array}$ & $\frac{354.5}{299 .,}$ & $\frac{19.1195}{1.2,159}$ & $\frac{1.344}{3.4189}$ & $\frac{2,41 !}{2,4 ! 1}$ & $\frac{5.6}{5.6}$ & $\frac{3,4,3}{6,3}$ & $\frac{4.9}{162}$ & $\begin{array}{r}3558 \\
667,3 \\
\end{array}$ & $\frac{2.0}{20.0}$ & $\frac{25.0}{283,1}$ & $\begin{array}{l}70 \\
70\end{array}$ & $\frac{200}{2000}$ \\
\hline & & 691.2. & & & 2,411 & 9,6 & $4,2.2$ & & 17509 & & 2027 & 7.0 & 1000 \\
\hline
\end{tabular}

Tabel 20. Water Balance tahun ke-2 untuk Alt.A padi-padi-palawija

\begin{tabular}{|c|c|c|c|c|c|c|c|c|c|c|c|c|c|}
\hline & \multirow{2}{*}{ rahua/Bulan } & Innow & Perikaanan & Irigasi & Domestik & Industri & Q Keburuhan & $\begin{array}{l}\text { Q Kebututhan } \\
\text { per bulann }\end{array}$ & $\begin{array}{c}\text { Tampungan } \\
\text { Bulananan }\end{array}$ & $S=1 \cdot 0$ & spillout & $\begin{array}{l}\text { Tampungan } \\
\text { Akhalr Bulan }\end{array}$ & permenhan \\
\hline & & m3idet & myvet & my/det & (m) hari & (m)'yet & 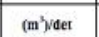 & 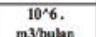 & 1076. & ${ }^{10^{\wedge} 6}$ & 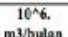 & 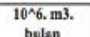 & $\%$ \\
\hline & $\begin{array}{l}2 \text { lanuari } \\
\text { Februari }\end{array}$ & $\frac{6164}{1024}$ & $\begin{array}{l}19.175 \\
19.175 \\
\end{array}$ & $\begin{array}{l}115459 \\
113096\end{array}$ & 24111 & $\begin{array}{l}55000 \\
5,000 \\
\end{array}$ & $\begin{array}{l}337 \\
3 \times 3\end{array}$ & $\frac{103.7}{102,5}$ & $\begin{array}{l}1733.8 \\
2629.8 \\
\end{array}$ & $\frac{1557.0}{2536,3}$ & $\frac{1650.0}{2527,3}$ & $\begin{array}{l}\frac{170.0}{7,0} \\
7,0\end{array}$ & $\begin{array}{l}1,00 \\
1,00\end{array}$ \\
\hline & $\begin{array}{l}\text { Narth } \\
\text { Apel }\end{array}$ & 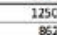 & 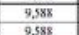 & 14140 & $\begin{array}{l}2411 \\
1236\end{array}$ & $\begin{array}{l}5,500 \\
5000\end{array}$ & $\begin{array}{l}31.7 \\
24.7\end{array}$ & $\frac{8510}{601}$ & $\begin{array}{l}32402,2 \\
22537\end{array}$ & $\begin{array}{l}3162,2 \\
212756\end{array}$ & $\begin{array}{l}3155,2 \\
211596.6\end{array}$ & $\begin{array}{l}7,0 \\
7,0\end{array}$ & $\frac{1.00}{100}$ \\
\hline & Nei & 27 & $\frac{0,000}{0.000}$ & $\frac{7,567}{7.64}$ & $\frac{1.206}{1206}$ & $\begin{array}{l}5,500 \\
500\end{array}$ & 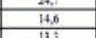 & $\begin{array}{l}3.910 \\
389 \\
89\end{array}$ & 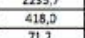 & $\begin{array}{l}3.186,0 \\
36,0 \\
6,5\end{array}$ & 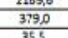 & $\frac{1,0}{7,0}$ & $\frac{1,00}{1,00}$ \\
\hline & $\frac{\text { unni }}{\text { juit }}$ & & $\begin{array}{l}0.000 \\
0,000\end{array}$ & $\frac{6.451}{0.000}$ & $\frac{1226}{241 !}$ & $\frac{5.600}{3000}$ & $\frac{13.5}{8.0}$ & $\frac{35,7}{21.5}$ & $\frac{7.2}{0.0}$ & $\frac{425}{1.45}$ & $\begin{array}{l}35.5 \\
0.0\end{array}$ & $\frac{7.0}{.14 .5}$ & $\frac{1.00}{0.00}$ \\
\hline & & 27 & $0,0,000$ & $\frac{0.000}{0.000}$ & 2411 & $\frac{5600}{5000}$ & 50 & $\frac{215}{215}$ & 0.0 & 35.9 & 0.0 & $\frac{.35,9}{3.9}$ & $\frac{0,00}{100}$ \\
\hline & 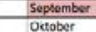 & 145 & $\frac{0,000}{0,000}$ & $\frac{0,000}{0.000}$ & $\frac{2411}{2411}$ & $\frac{5,500}{2000}$ & & $\begin{array}{l}21.15 \\
140\end{array}$ & $\begin{array}{l}57,0 \\
35.8\end{array}$ & 361.5 & $\frac{0.0}{3.655}$ & $\frac{0,4}{10}$ & $\frac{1,00}{1.00}$ \\
\hline & & & & & & & & & & & & 7,0 & $\begin{array}{l}1,00 \\
1,00\end{array}$ \\
\hline & Desember & (1) & 19,175 & 16924 & 2411 & 2.8500 & & 110.8 & 1770,9 & 1587,2 & 1680,2 & 7,0 & 1,00 \\
\hline
\end{tabular}

Tabel 21. Water Balance tahun ke- 2 untuk data eksisting padi-palawija-palawija

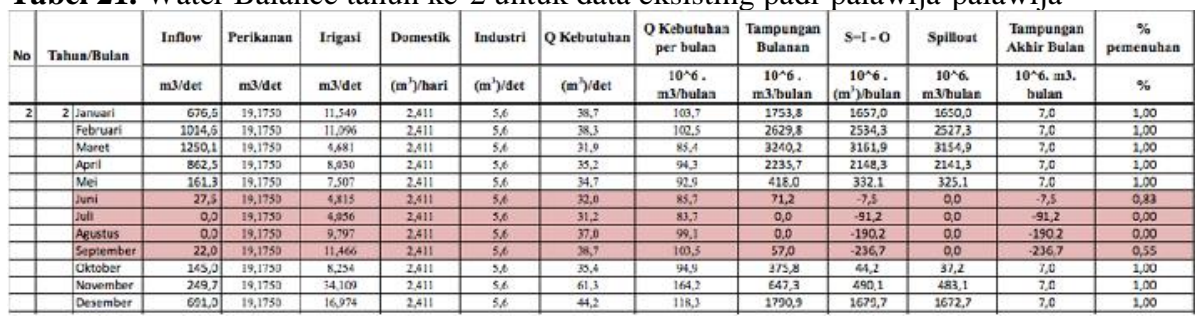

Tabel 22. Water Balance tahun ke-2 untuk Alt.A padi-palawija-palawija

\begin{tabular}{|c|c|c|c|c|c|c|c|c|c|c|c|c|c|}
\hline & \multirow{3}{*}{ Thabun Bulan } & & & & & & & & & \\
\hline & & Inflow & Perikicanar & ritases & Domestik & Industit & Q Kebutthan & $\begin{array}{c}\text { Q Kebutuhan } \\
\text { per bulan }\end{array}$ & 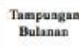 & 5-1-0 & Spillost & $\begin{array}{l}\text { Tampongzan } \\
\text { Mkthir Bulan }\end{array}$ & $\%$ pemenuhan \\
\hline & & myldet & (m) $\mathrm{m}^{3}$ duct & $\left(\mathrm{m}^{2}\right.$ ) Vut & (an')/det & (min') ocs & $\left(\mathrm{I}^{2}\right)$ )ut & $10^{\circ} 6$. matoulan & $10 \%$ & 1076. & 106.6 & $100 . \mathrm{m3}$. & $\%$ \\
\hline & 2 |lanvari & 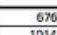 & 19,1750 & & 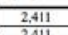 & 5.6 & $\begin{array}{l}8.1 \\
4.15\end{array}$ & 128 & 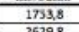 & $\begin{array}{l}2651,9 \\
25079\end{array}$ & 2025,3 & 7,0 & 1,00 \\
\hline & & & $\frac{10000}{0.0000}$ & & & & & & & & & & \\
\hline & Apsil & 862 & 0.0000 & 10.467 & 2,411 & 2.8 & $\overline{15.7}$ & 42.0 & 2235,7 & 2200,7 & $2: 93,7$ & 7,0 & $\infty$ \\
\hline & $f_{0}^{N e}$ & $\frac{161}{63}$ & 0,00500 & 10,467 & & & & & & & 376,0 & , & 1,000 \\
\hline & tont & 210 & 000000 & 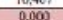 & $\frac{1.910}{1206}$ & $\frac{28}{56}$ & & & & $\frac{2.2}{112}$ & $\frac{2,2}{0.0}$ & $\frac{1,0}{-1.2}$ & 1,000 \\
\hline & 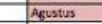 & & 0,0000 & 0,000 & 1,206 & .90 & 6.8 & & & & 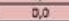 & 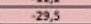 & 0,00 \\
\hline & Sesptember & 2 & 0.0000 & 0.0001 & 1.206 & 5.6 & 6.8 & 18,2 & 57,0 & 93 & 23 & 7.0 & 1.00 \\
\hline & 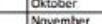 & $\frac{135}{203}$ & $\frac{0.0000}{61908}$ & $\frac{0.003}{0.0977}$ & $\frac{2.411}{24 !}$ & $\frac{3.6}{56}$ & $\frac{8.0}{48}$ & $\frac{21,3}{1789}$ & $\frac{3158}{6153}$ & 年 & $\frac{32,4}{5184}$ & 7,0 & 1,00 \\
\hline & 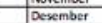 & $\frac{6.691}{6912}$ & $\frac{191,150}{19.1750}$ & 20.933 & $\frac{2.41}{2.41}$ & 5.6 & $\frac{7.1}{48,1}$ & $\frac{1289}{1289}$ & $\begin{array}{l}0.17,3 \\
1790,9\end{array}$ & $\frac{35,4}{1669,1}$ & $\begin{array}{l}1518,4 \\
1662,1\end{array}$ & 7,0 & 1,00 \\
\hline
\end{tabular}


Tabel 22. Kebutuhan air total pada setiap alternative dan tingkat pemenuhan airnya

\begin{tabular}{lcc}
\hline \multicolumn{1}{c}{ Alternative } & $\begin{array}{c}\text { Total Water } \\
\text { Requirement } 10^{6} \mathrm{~m}^{3}\end{array}$ & \% fulfillment (\%) \\
\hline Data eksisting padi-padi-padi & 77329,82 & $81,54 \%$ \\
Data eksisting padi-padi palawija & 67897,01 & $82,53 \%$ \\
Data eksisiting padi-palawija-palawija & 61411,61 & $88,96 \%$ \\
Alt. A padi-padi-padi & 38357,07 & $88,91 \%$ \\
Alt. A padi-padi-palawija & 38897,47 & $90,10 \%$ \\
Alt. A padi-palawija-palawija & 33086,86 & $87,17 \%$ \\
\hline
\end{tabular}

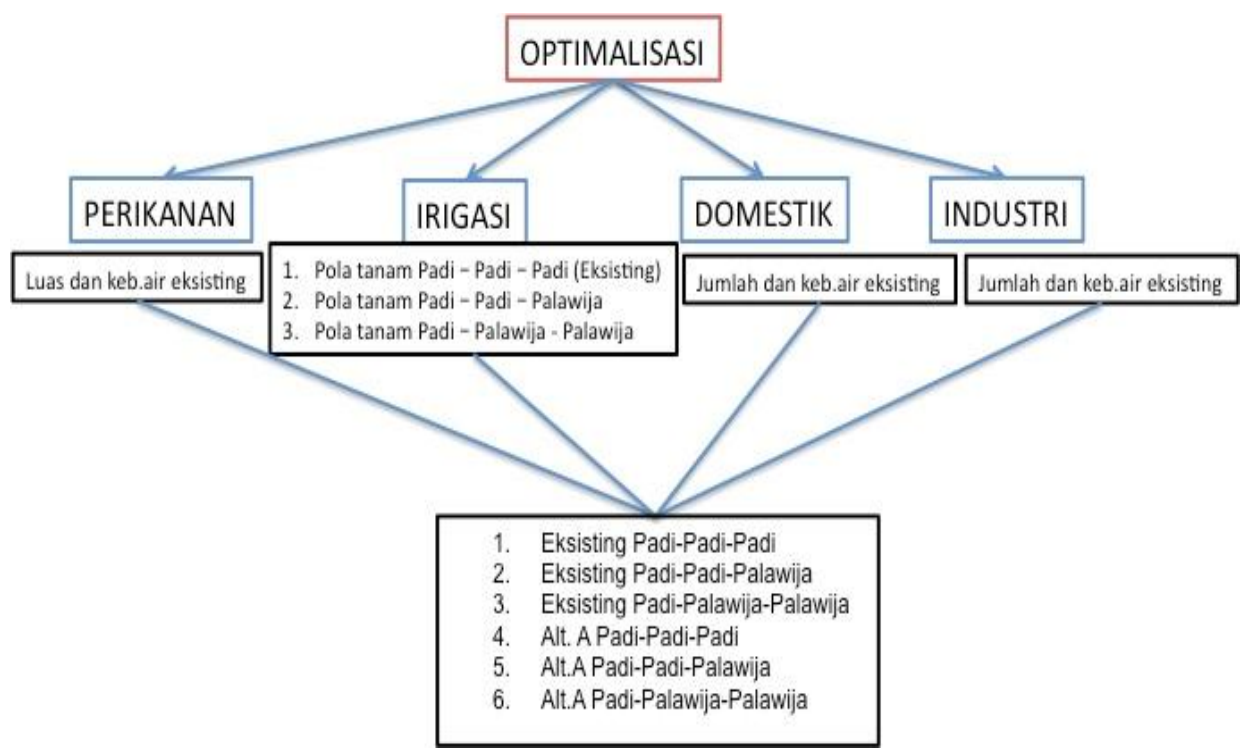

Gambar 1. Skema Bentuk Optimalisasi

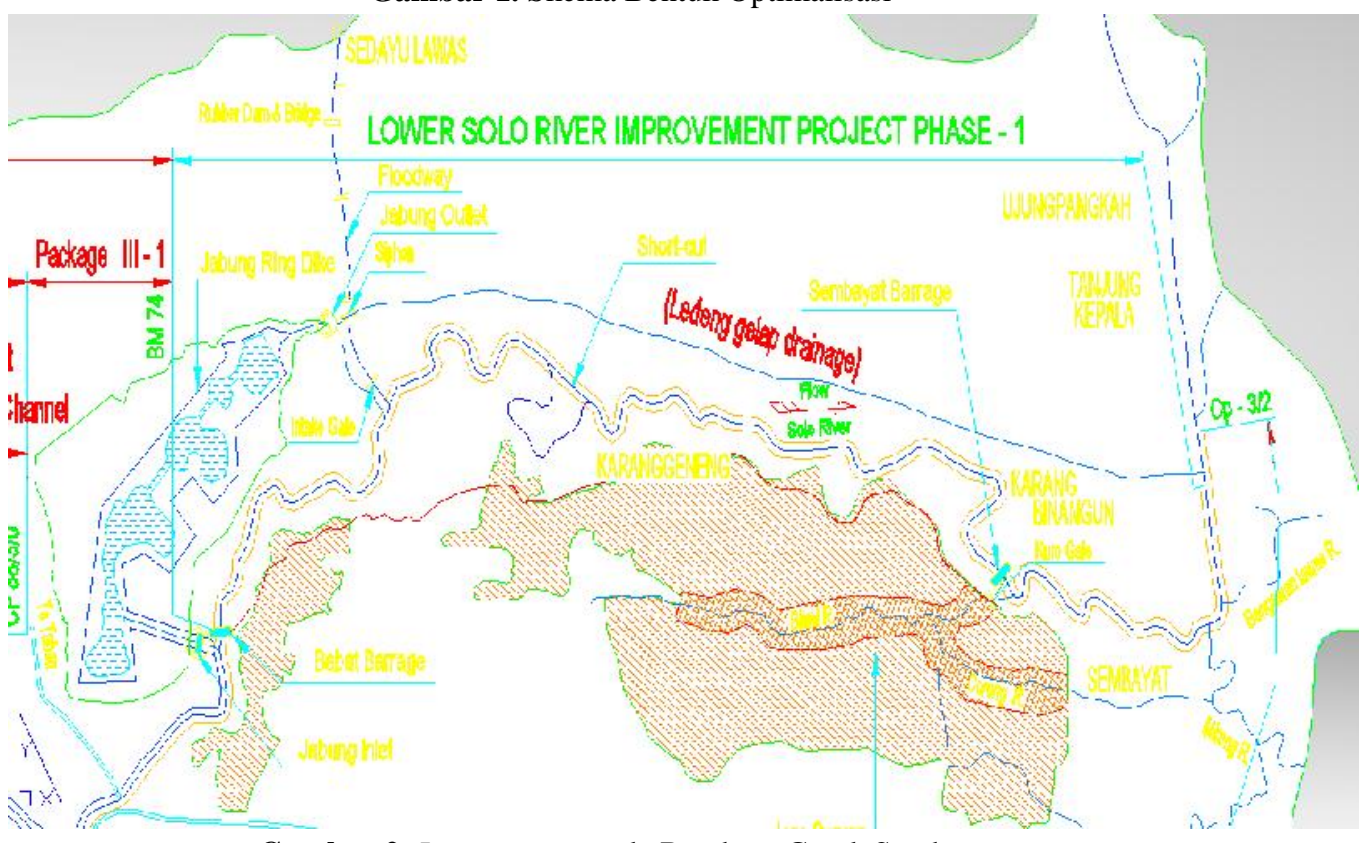

Gambar 2. Longstorage pada Bendung Gerak Sembayat 


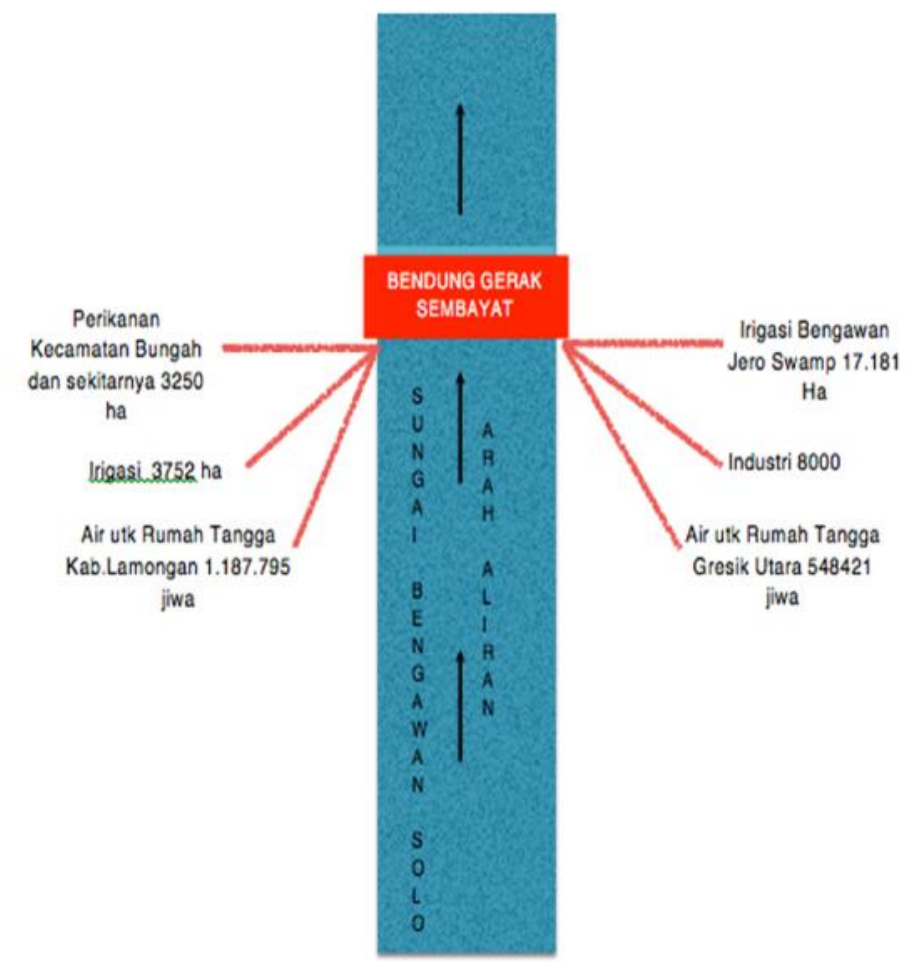

Gambar 3. Skema Pendistribusian Air pada Area Eksisting Bendung Gerak Sembayat

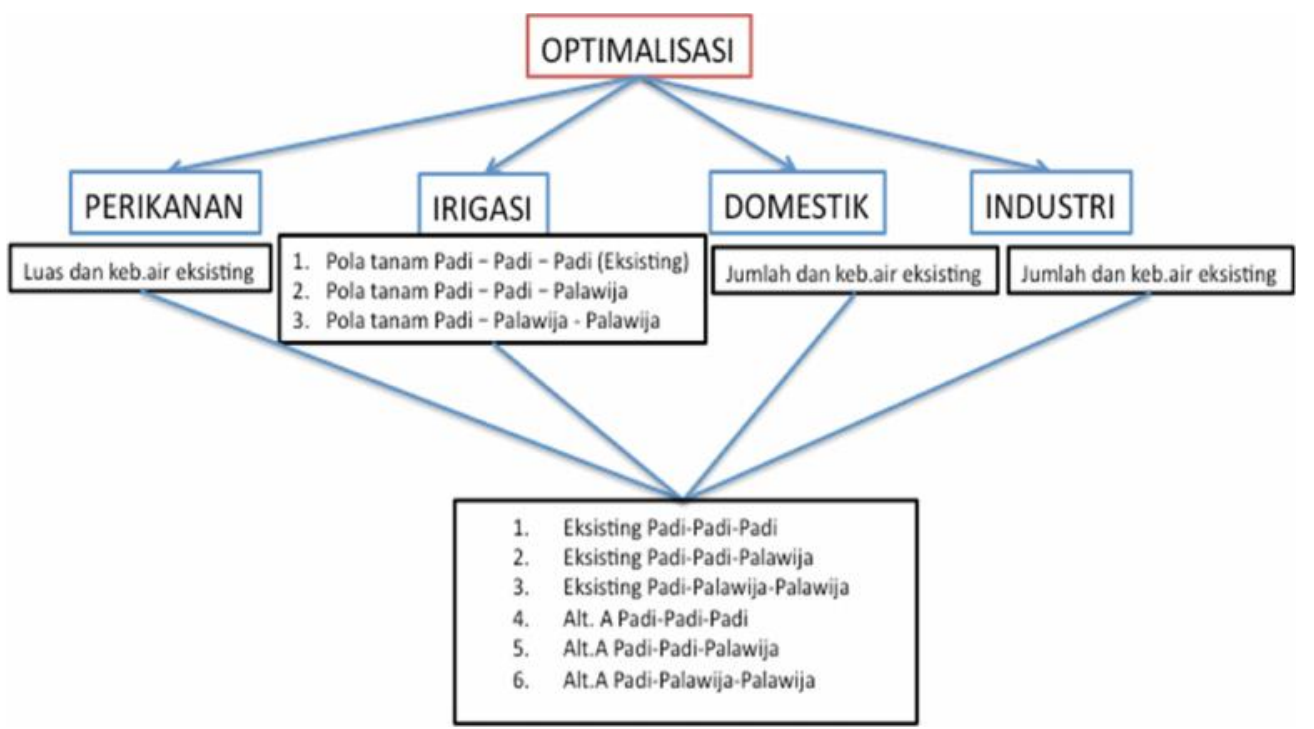

Gambar 4. Skema Strategi Pemenuhan Air Pada Bendung Gerak Sembayat 


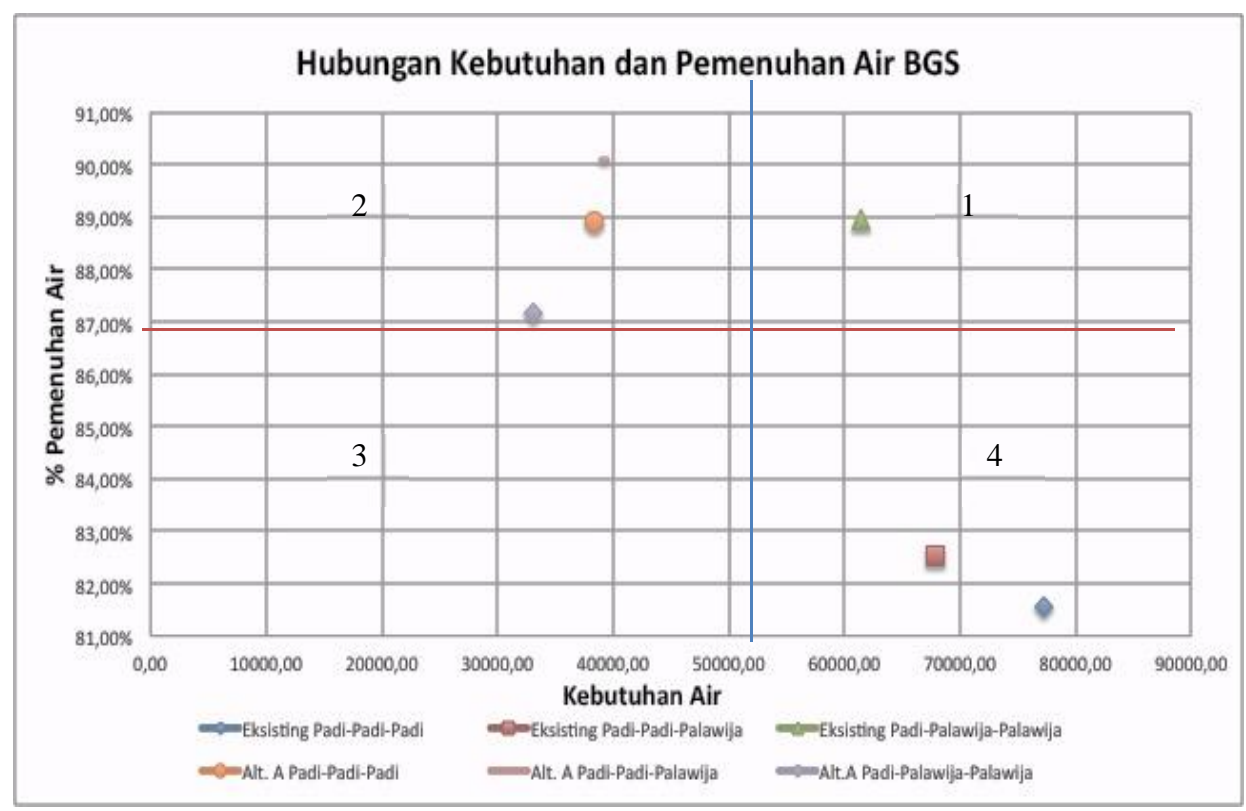

Gambar 5. Hubungan kebutuhan air dan pemenuhan air pada Bendung Gerak Sembayat 
